\title{
A solar combi-system utilizing stable supercooling of sodium acetate trihydrate for heat storage: Numerical performance investigation
}

EngImair, Gerald; Moser, Christoph; Schranzhofer, Hermann; Fan, Jianhua; Furbo, Simon

Published in:

Applied Energy

Link to article, DOI:

10.1016/j.apenergy.2019.03.125

Publication date:

2019

Document Version

Peer reviewed version

Link back to DTU Orbit

Citation (APA):

Englmair, G., Moser, C., Schranzhofer, H., Fan, J., \& Furbo, S. (2019). A solar combi-system utilizing stable supercooling of sodium acetate trihydrate for heat storage: Numerical performance investigation. Applied Energy, 242, 1108-1120. https://doi.org/10.1016/j.apenergy.2019.03.125

\section{General rights}

Copyright and moral rights for the publications made accessible in the public portal are retained by the authors and/or other copyright owners and it is a condition of accessing publications that users recognise and abide by the legal requirements associated with these rights.

- Users may download and print one copy of any publication from the public portal for the purpose of private study or research.

- You may not further distribute the material or use it for any profit-making activity or commercial gain

- You may freely distribute the URL identifying the publication in the public portal 


\title{
A solar combi-system utilizing stable supercooling of sodium acetate trihydrate for heat storage: numerical performance investigation
}

\author{
Gerald Englmair ${ }^{1,2}$, Christoph Moser $^{3}$, Hermann Schranzhofer ${ }^{3}$, Jianhua Fan $^{2}$ and Simon Furbo ${ }^{2}$ \\ ${ }^{1}$ Sino-Danish Center, University of Chinese Academy of Sciences, 380 Huaibeizhuang, Huairou district, Beijing, China \\ ${ }^{2}$ Department of Civil Engineering, Technical University of Denmark, Brovej 118, 2800 Kgs. Lyngby, Denmark \\ ${ }^{3}$ Institute of Thermal Engineering, Graz University of Technology, Inffeldgasse 25/B, 8010 Graz, Austria
}

\section{Highlights}

- On-demand crystallization of sodium acetate trihydrate for heat storage

- A numerical model was validated with data from system demonstration

- Sensitivity analysis of solar collector area and heat storage volume

- Annual solar fraction of $71 \%$ with $0.6 \mathrm{~m}^{3}$ water and $1 \mathrm{~m}^{3}$ of PCM for heat storage

- $1000 \mathrm{kWh}$ of heat supplied by PCM units with 5.5 annual heat storage cycles

\begin{abstract}
To reduce the energy consumption of buildings significantly, a novel solar combi-system with short and long-term heat storage has been developed. A system prototype with $22.4 \mathrm{~m}^{2}$ (aperture) evacuated tubular collectors, a $735 \mathrm{~L}$ water tank and 4 phase change material (PCM) units each containing $150 \mathrm{~L}$ sodium acetate trihydrate composite has been built. Experimental investigation has shown advantages of utilization of stable supercooling of sodium acetate trihydrate in spring and autumn. In this paper, a newly developed numerical model was used to investigate the performance potential of the system with combined utilization of the water tank and the PCM units, including on-demand crystallization of supercooled sodium acetate trihydrate composites. PCM units, the water tank and the collector circuit models were validated with measurement data from system demonstration. Space heating and hot water demand patterns of a Danish single-family Passive House with a yearly heat demand of $3723 \mathrm{kWh}$ were applied. Results showed that a $56 \%$ annual solar fraction of heat supply was achieved with the prototype specifications. A 69\% solar fraction could be achieved with an optimized scenario including a $15 \%$ increased hot water demand. Sensitivity analysis of component sizing showed that PCM units of $200 \mathrm{~L}$ can be more efficiently used with a $0.6 \mathrm{~m}^{3}$ water tank. Optimal solar collector array tilt was $70^{\circ}$. Aperture areas between 12.8 and $22.4 \mathrm{~m}^{2}$ were found adequate for frequent utilization of a PCM volume up to $1 \mathrm{~m}^{3}$. Thus, the PCM heat storage capacity could be utilized at least 5.5 times a year. With a $22.4 \mathrm{~m}^{2}$ collector area and 5 PCM units of $200 \mathrm{~L}$ each, a solar fraction of $71 \%$ was calculated for the annual heat supply. Assuming full charge of a $0.6 \mathrm{~m}^{3}$ water tank and $2.8 \mathrm{~m}^{3}$ of sodium acetate trihydrate composite by electricity at the beginning of the year, the system could run 18 days without need for auxiliary heating. Thus, in periods without solar collector power available, generation maxima of wind power could be utilized. In conclusion, building heat demand could be covered close to $100 \%$ by renewable energy resources.
\end{abstract}

Keywords: Solar heating system; phase change material; sodium acetate trihydrate; stable supercooling; Passive House; numerical simulation. 


\section{Nomenclature}

\section{Symbols}

$\begin{array}{llll}\text { A } & \text { collector array aperture area }\left(\mathrm{m}^{2}\right) & \text { meas } & \text { measured value } \\ \mathrm{C} & \text { heat capacity }(\mathrm{kWh}) & \text { out } & \text { outlet line } \\ \mathrm{G}_{\text {total }} & \text { global irradiance; collector plane }\left(\mathrm{W} / \mathrm{m}^{2}\right) & \text { PCM } & \text { phase change material } \\ \mathrm{I} & \text { collector array inclination }\left(^{\circ}\right) & \text { return } & \text { return temperature } \\ \mathrm{N}_{\text {cycle }} & \text { number of storage cycles per year }(-) & \mathrm{sec} & \text { secondary circuit } \\ \mathrm{Q} & \text { thermal energy, heat }(\mathrm{kWh}) & \mathrm{SH} & \text { space heating } \\ \dot{\mathrm{Q}} & \text { heat transfer rate }(\mathrm{kW}) & \text { sim } & \text { simulation value } \\ \dot{\mathrm{Q}} \text { coll } & \text { collector power at the heat exchanger }(\mathrm{kW}) & \text { solar } & \text { net utilized solar energy } \\ \mathrm{q}_{\text {coll }} & \text { specific solar yield }\left(\mathrm{kWh} / \mathrm{m}^{2}\right) & \text { total } & \text { total, on the collector plane } \\ \mathrm{t} & \text { time }(\mathrm{s}) & \text { water } & \text { water tank }\end{array}$

$\mathrm{T}$ temperature $\left({ }^{\circ} \mathrm{C}\right)$

$\mathrm{V} \quad$ Volume $\left(\mathrm{m}^{3}\right)$

$\dot{\mathrm{V}} \quad$ volume flow rate (L/min)

Abbreviations

DHW domestic hot water

E electrical heating element

Subscripts

HTF heat transfer fluid

aux auxiliary

IAM incidence angle modifier

coll collector outlet

PCM phase change material

charge charge RE

cycle cycles per year

REF renewable energy fraction

DHW domestic hot water

SF

solar fraction of heat supply

discharge discharge

SAT

sodium acetate trihydrate

flow flow temperature

$\mathrm{SH}$

space heating

TRNSYS transient system simulation tool 


\section{Introduction}

\subsection{Concepts for high solar fractions of building heat supply}

In Europe, the energy consumption in buildings accounts for $40 \%$ of the total energy supply [1]. Since heating accounts for the largest share of this consumption, a near-zero energy consumption is required from all new buildings by the EU Energy Performance of Buildings Directive in 2010 [2] from 31 ${ }^{\text {st }}$ December 2020.

Solar combi-systems for space heating (SH) and domestic hot water (DHW) supply can contribute to achieve this goal by heat generation, storage and supply in buildings [3]. The biggest challenge is the mismatch between availability of solar resources and heat demands. Lower operation temperatures of collector circuit and heat storage and low heat storage losses by compact system design have been identified as key factors for well-performing systems [4], [5]. Thus, solar fraction (SF) of heat supply (net utilized solar energy divided by SH and DHW demand) can be improved.

To achieve high SF, energy-efficient building envelopes and optimal DHW supply temperatures are the basis. The Danish code of practice for domestic water supply, DS 439 [6], recommends a hot water temperature of $45^{\circ} \mathrm{C}$ as sufficient to fulfil comfort requirements. To utilize solar irradiation during the heating season, a relatively large collector area is required as well as optimization of the collector tilt, which depends on the latitude [7].

In Germany, energy-efficient "solar active houses" with large solar collector arrays and water stores, enabling solar fractions close to $100 \%$, have been reported [8]. To achieve well-performing solar combi-systems with moderate collector area and more compact heat storage, long-term heat storage concepts have been tested: Sorption systems with zeolites or composites of zeolite and salt as storage material could store solar heat during summer for heat supply in winter [9]. Open reactors have been demonstrated in laboratory scale [10]. Zettl et al. have developed a process with solar air collectors for regeneration of zeolite pebbles [11], which can be utilized for heat supply via a rotating drum-reactor [12]. A closed sorption system utilizing flat plate collectors for regeneration of zeolites achieved a solar fraction of $83.5 \%$ during laboratory testing in winter [13]. Evacuated tubular solar collectors can be used for regeneration in a liquid sorption heat storage with sodium hydroxide [14], the concept was recently proved by Fumey et al. [15]. Phase change materials (PCM) are applicable in low and medium temperature applications [16], where a high potential for building applications was found [17]. PCM with optimized melting temperatures can be utilized as passive thermal energy storage in the building envelope, leading to notable reduction of heat demand [18]. PCM could be also utilized in a photovoltaic/ thermal system to increase electrical and thermal energy efficiency [19] and to prevent thermal systems from freezing in winter [20].

Sodium acetate trihydrate (SAT), a salt hydrate with a melting temperature of $58^{\circ} \mathrm{C}$, has the ability to supercool stably to ambient temperatures while preserving its heat of fusion [21], [22]. It is therefore considered as PCM for the investigated solar system due to its capability for long-term heat storage.

Rathgeber et al. [23] made a top-down evaluation of acceptable costs of energy stores for buildings, based on their energy storage capacity. Results imply that long-term heat storage concepts are only economically attractive when applications enable a certain number of annual storage cycles. The number mainly depends on costs for storage material, container and heat exchanger.

In general, PCM heat stores and thermochemical processes for long-term heat storage are assumed to be more 
expensive than heat storage by water tanks. To achieve the optimal number of annual heat storage cycles, integration into a future energy system should be considered. For example, energy storage with PCM can help to overcome the mismatch between renewable electricity generation and hot water, heating and cooling demand [24]. Wind as the most dominant contributor to renewable power generation is stronger during winter than in summer across Europe [25]. Because of occurring overproduction of wind turbines in windy periods, it is economically attractive to integrate wind power into the heat market in Denmark, so the excess wind power can be consumed for heating of buildings [26]. Solar combi-systems could become more attractive when collector arrays are sized for optimal annual yield, avoiding stagnation periods, and cheap electricity is stored in long-term heat storages, allowing year-round heat supply with renewable energy sources.

\subsection{Heat stores utilizing stable supercooling of SAT}

The latent heat of fusion of pure SAT has been determined to be $264 \mathrm{~kJ} / \mathrm{kg}$ [27]. To overcome phase separation of the incongruently melting salt, full dissolving of sodium acetate in its crystal water can be achieved by adding extra water [28] and by avoiding water concentration differences in large volumes containing SAT in liquid phase [29]. To achieve stable SAT compositions and to avoid the need for mechanical mixing of melted SAT, thickening agents and liquid additives have been applied and tested for their thermal conductivity [30], porosity and density [31] and heat content in supercooled state [32]. Crystallization of supercooled SAT composites can be either initialized by seed crystal injection [22], [33] or by local cooling to temperatures below $-15^{\circ} \mathrm{C}[34]$.

Different concepts have been developed to overcome heat transfer restriction of solid PCM in domestic heat stores. Commercially available heat exchangers for use in PCM heat stores were evaluated by Medrano et al. [35]. Internal tube bundle heat exchangers were tested in a large PCM container [36]. Another way was to realize sensible-latent heat storage with macro-encapsulated PCM in water vessels [37] or shell-and-tube heat exchangers with PCM filling [38].

Zhou and Xiang [39] tested rectangular and slim cylindrical vessels containing SAT composites with extra water and with carboxymethyl cellulose. They reported engineering challenges to achieve stable supercooling. Those challenges have been addressed previously by designing flat [40] and cylindrical [41] heat storage prototypes. Stable supercooling was enabled by avoidance of pressure changes in the PCM container, smooth inner container surfaces and heat up of the whole material volume to a minimum temperature of $77^{\circ} \mathrm{C}$. Also application of SAT in the mantle of hot water tanks was tested [42].

\subsection{Development of a novel solar combi-system}

In previous work at the Technical University of Denmark (DTU), it was investigated how heat stores utilizing stable supercooling of SAT could be used for solar heating in buildings (a-c):

a) As a pre-study in 2015, Dannemand et al. [43] simulated an application in a standard-size Passive House in Danish climate. A simple energy balance model with SAT properties from literature [44], was used for the heat storage. The authors found that a system with several individual flat units, forming a segmented PCM heat storage, would work best. Simulations with 10 units, containing in total $1.5 \mathrm{~m}^{3}$ of SAT, and $36 \mathrm{~m}^{2}$ flat plate collectors resulted in annual solar fractions of over $75 \%$. 
b) Based on this promising results, a segmented heat storage prototype with four flat PCM units [40], containing $150 \mathrm{~L}$ of different SAT composites each and a $735 \mathrm{~L}$ water tank was built and tested for utilization in a solar heating system [45]: Functionality tests with an evacuated tubular collector array proved combined short and long-term heat storage by PCM units. Starting from solid state at room temperature, $27.4 \mathrm{kWh}$ of solar heat was stored in a single PCM unit. Parallel charging of PCM units was necessary to match their limited heat transfer capacity with fluctuating solar collector power. Stored sensible heat was transferred from PCM units to the water tank. Afterwards, SAT composites supercooled stably to room temperature. SAT composite solidification was then initialized by seed crystal injection and $10.4 \mathrm{kWh}(80 \%$ of heat of fusion) of heat was discharged. Because of heat transfer restrictions a heat transfer fluid (HTF) flow rate of $2 \mathrm{~L} / \mathrm{min}$ and a final SAT composite temperature of $50{ }^{\circ} \mathrm{C}$ needed to be applied to heat a water tank. Therefore $20 \%$ of heat of fusion remained in the warm SAT composite and container.

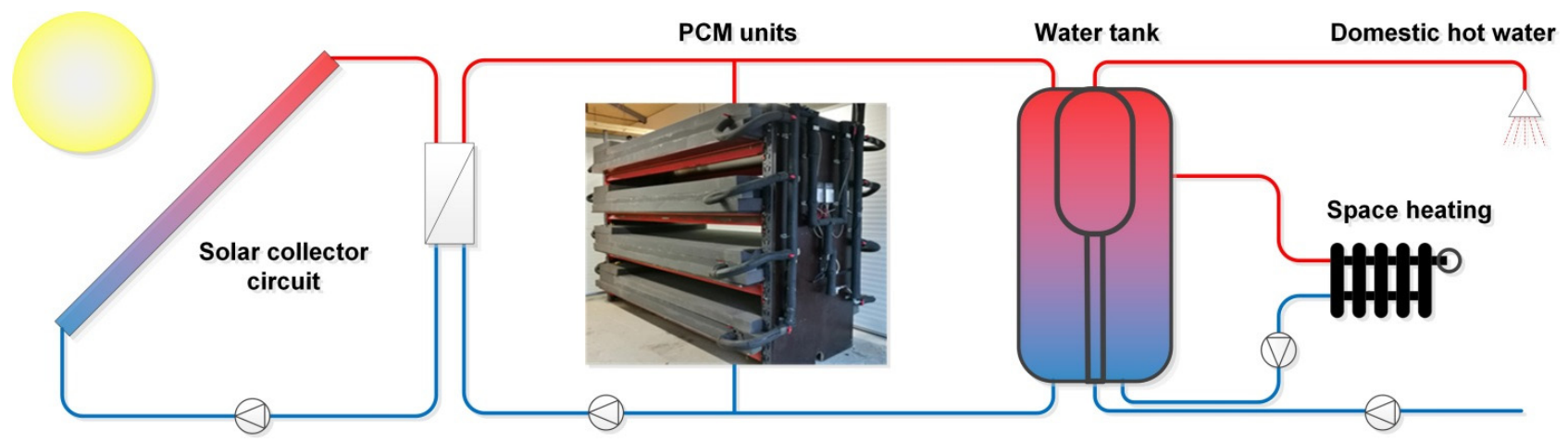

Fig. 1. Diagram of the tested solar combi-system utilizing stable supercooling of SAT.

c) The prototype was implemented in a solar combi-system with $22.4 \mathrm{~m}^{2}$ (aperture) evacuated tubular collectors (Fig. 1). It was demonstrated with SH and DHW demand patterns of a $130 \mathrm{~m}^{2}$ Passive House in Danish climate. A strategy for charging [46] and discharging of water tank and PCM units was developed (see section 2). Automated operation was realized by a monitoring system and a control program. Data analysis showed that heat stores were efficiently utilized in spring and autumn 2016. However, SAT composite crystallization needed to be initialized manually, and thus studying the annual system performance was not possible.

\subsection{Scope}

To the authors' best knowledge, the application potential of recently developed heat stores utilizing stable supercooling of SAT has never been investigated before. Based on the outcome of the previous work (section 1.3), the following gap of knowledge was addressed:

- Annual system performance: On-demand utilization of heat of fusion of SAT has not been possible during automated operation of the developed solar heating system. Full-performance investigation, including possible solar fraction of heat supply, must be thus conducted with a numerical model.

- Development of a realistic system model: In contrary to the pre-study, solar collector array, water tank and PCM units were modelled and validated using data from experimental work. SAT composite properties were implemented 
in the PCM unit model. System simulation was conducted with an experimentally developed control strategy, considering a hot water supply temperature of $45^{\circ} \mathrm{C}$.

- Sizing of system components: The optimal solar collector area and heat storages volumes are determined by means of sensitivity analysis considering economic aspects.

- Integration into a future energy system: By power-to-heat conversion, buildings will serve as one possible source of demand flexibility in future electrical grids [47]. The demand flexibility of systems utilizing stable supercooling of SAT composites was never investigated before.

Numerical simulation results for full potential analysis of a solar combi-system utilizing stable supercooling of SAT are presented. For this purpose specification of the first system demonstrator of its kind as well as characteristic space heating and hot water demand patterns of a standard-sized Danish Passive House were applied. The performance potential of the system was studied in a scenario without identified restrictions of the system demonstrator.

The goals were to investigate how component sizing influences the solar fraction of the system and which system configurations would be economically attractive. The potential for integration in a future energy system was elucidated in a scenario assuming full storage charge by wind power at the beginning of the year, when no solar collector power was available.

\section{Layout and applied control strategy of the system}

Settings of seven operation modes (A-G) have been developed and their applicability has been previously demonstrated. Fig. 2 illustrates how the solar combi-system was operated in modes B-F. The following control strategy was applied in the numerical system model:

- System standby (mode A): Water tank coverage is sufficient for DHW and SH supply.

- Water tank charging (mode B, Fig. 2 a): The mode starts when the collector outlet temperature $\left(\mathrm{T}_{\text {coll }}\right)$ is $10 \mathrm{~K}$ higher than $\mathrm{T}_{1}$ and the temperature in the middle of the water tank $\left(\mathrm{T}_{2}\right)$ is below $50^{\circ} \mathrm{C}$. During operation, $\mathrm{T}_{\text {coll }}$ must be at least $2 \mathrm{~K}$ higher than the temperature at the bottom of the water tank $\left(\mathrm{T}_{1}\right)$. Water tank charging stops when $\mathrm{T}_{2}$ reaches $60{ }^{\circ} \mathrm{C}$.

- PCM heat storage charging (mode C, Fig. 2 b): A total irradiance on the tilted collector plane $\left(\mathrm{G}_{\text {total }}\right)$ of at least $150 \mathrm{~W} / \mathrm{m}^{2}$ must be measured or $\mathrm{T}_{\text {coll }}$ must be at least at $70{ }^{\circ} \mathrm{C}$. The mode starts when $\mathrm{T}_{2}$ is above $60{ }^{\circ} \mathrm{C}$ and it is interrupted by water tank charging (mode $\mathrm{B}$ ) when $\mathrm{T}_{2}$ falls below $50{ }^{\circ} \mathrm{C}$. Units with a PCM temperature $\left(\mathrm{T}_{\mathrm{PCM}}\right.$ ) below $80^{\circ} \mathrm{C}$ are subject to charge, where the warmest unit has priority. Charging starts with a single unit, the next warmer unit is charged in parallel if the flow temperature $\left(\mathrm{T}_{\text {sec flow }}\right)$ exceeds $95{ }^{\circ} \mathrm{C}$. When $\mathrm{T}_{\text {sec flow }}$ falls below $85^{\circ} \mathrm{C}$, the coldest unit is removed from the charging circuit. The mode stops when the PCM in all units reaches a temperature of at least 80 ${ }^{\circ} \mathrm{C}$.

- Additional water tank charging (mode D, Fig. 2 a): When all PCM units are fully charged and $\mathrm{T}_{\text {coll }}$ is $10 \mathrm{~K}$ higher than $\mathrm{T}_{1}$, additional water tank charging takes place. It stops when $\mathrm{T}_{\text {coll }}$ is less than $2 \mathrm{~K}$ higher than $\mathrm{T}_{1}$, or if stagnation conditions occur.

- PCM discharge of sensible heat (mode E, Fig. 2 c): Without collector power available and a temperature at the middle 
of the tank $\left(\mathrm{T}_{2}\right)$ below $45{ }^{\circ} \mathrm{C}$, heat from the warmest PCM unit is transferred to the water tank. When $\mathrm{T}_{\mathrm{PCM}}$ falls below $50{ }^{\circ} \mathrm{C}$ the next warmest unit is discharged. The mode stops when either $\mathrm{T}_{2}$ reaches $45{ }^{\circ} \mathrm{C}$, or all PCM temperatures become too low.

- $\quad$ PCM discharge of heat of fusion (mode F, Fig. 2 c): When threshold conditions for mode E are reached, but PCM unit temperatures are too low, SAT composite solidification of the warmest, supercooled unit is initialized by means of seed crystal injection. Heat transfer fluid flow starts when $\mathrm{T}_{\mathrm{PCM}}$ rises to $58{ }^{\circ} \mathrm{C}$. When $\mathrm{T}_{\mathrm{PCM}}$ is lower than $50{ }^{\circ} \mathrm{C}$, the procedure is repeated with the next warmest, supercooled unit. The mode stops when either $\mathrm{T}_{2}$ reaches $45{ }^{\circ} \mathrm{C}$, or when all PCM temperatures become too low.

- Auxiliary heating (mode $\mathrm{G}$ ): When no collector power is available, $\mathrm{T}_{2}$ and $\mathrm{T}_{3}$ (top of the tank) are below $45^{\circ} \mathrm{C}$, $\mathrm{PCM}$ temperatures are below $50{ }^{\circ} \mathrm{C}$ and SAT composites are in solid state, an auxiliary heating element $\left(\mathrm{E}_{\text {aux }}\right)$ is switched on in the water tank. The mode stops when $\mathrm{T}_{3}$ reaches $45^{\circ} \mathrm{C}$.

a)

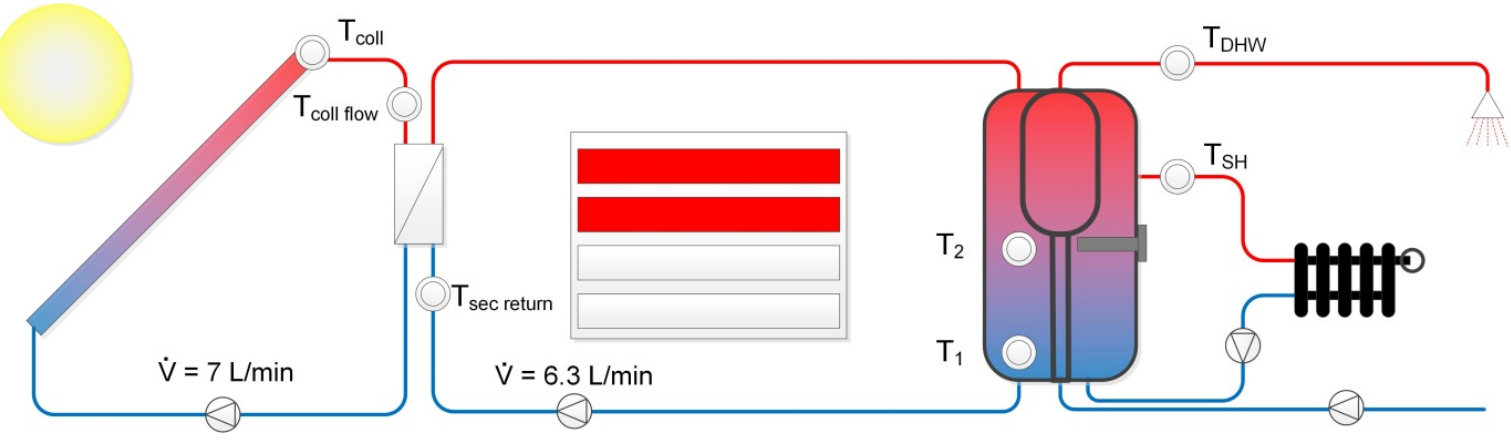

b)

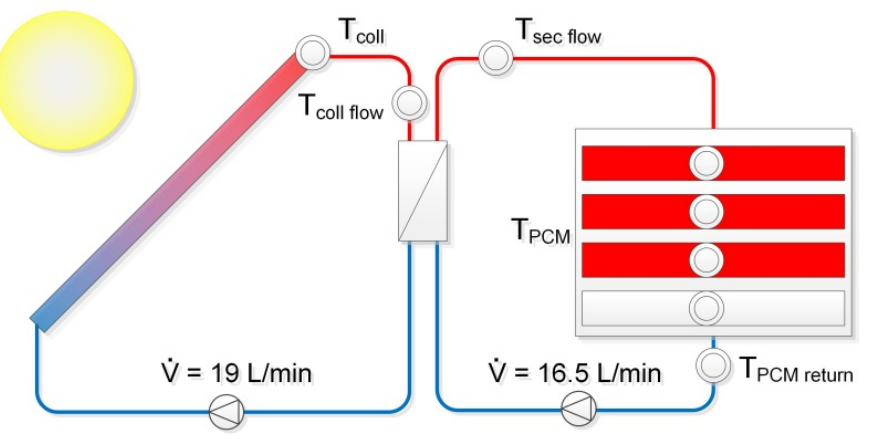

$\mathrm{T}_{2}$
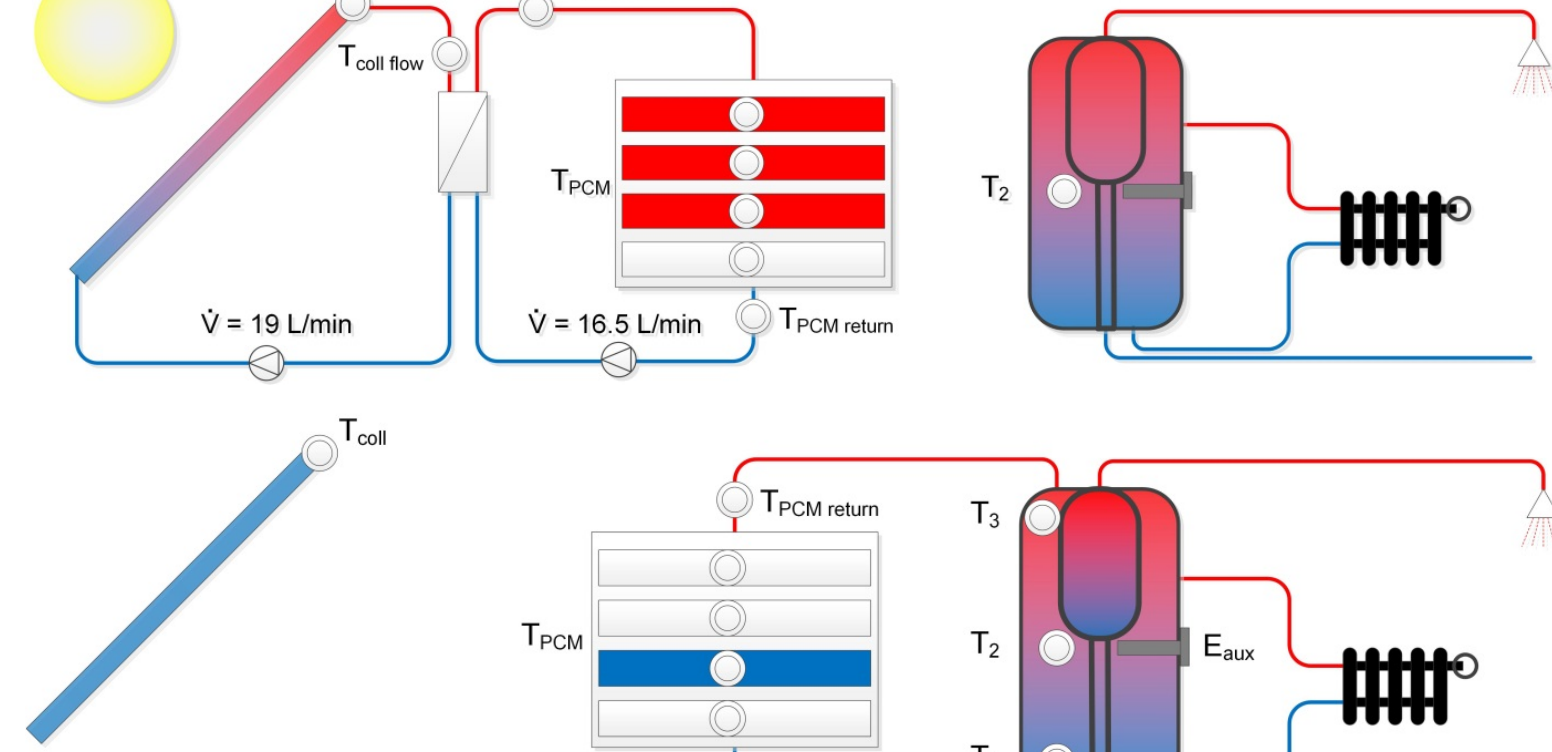

c)

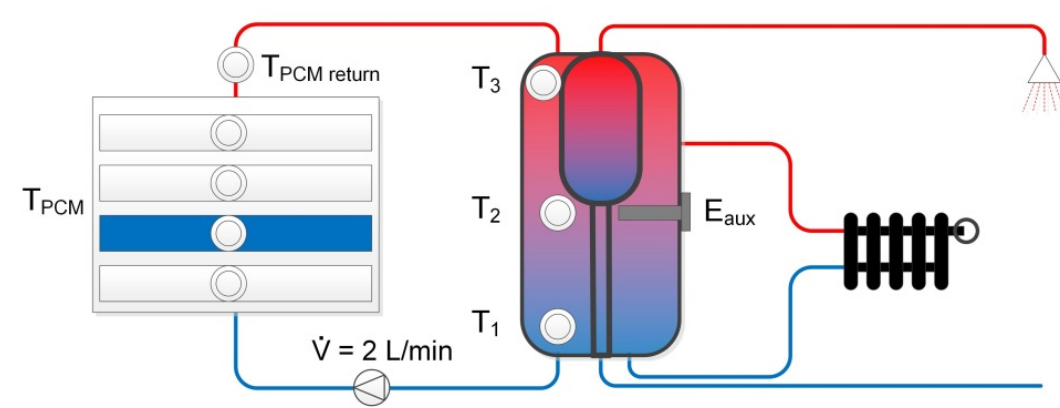

Fig. 2. Diagram of operation schemes: a) Modes B and D; b) Mode C; c) Modes E and F. 


\section{Method}

\subsection{System model}

A numerical model was built in TRNSYS 17 environment. The water tank model, type 8893, the multiple flat PCM unit model, type 8888 and the controller of PCM units, type 8889 , have been previously developed by authors of this article. The system control strategy (section 2) was implemented via the newly developed controller type 8896.

The collector array was modeled with type 538, using specifications of 7 evacuated tubular collector panels, type Thermomax HP 450 from Kingspan Renewables, see Table 1. The parameters in the table are based on the aperture area of the collector.

Table 1. Data from collector panel certification [48].

\begin{tabular}{|c|c|c|c|c|c|c|}
\hline & $\begin{array}{c}\text { Aperture } \\
\text { area } \\
\left(\mathrm{m}^{2}\right)\end{array}$ & $\begin{array}{c}\text { Gross area } \\
\left(\mathrm{m}^{2}\right)\end{array}$ & $\begin{array}{l}\text { Peak collector } \\
\text { efficiency (-) }\end{array}$ & $\begin{array}{c}1^{\text {st }} \text { order loss } \\
\text { coefficient } \\
\left(\mathrm{W} / \mathrm{m}^{2} \mathrm{~K}\right)\end{array}$ & $\begin{array}{c}2^{\text {nd }} \text { order loss } \\
\text { coefficient } \\
\left(\mathrm{W} / \mathrm{m}^{2} \mathrm{~K}^{2}\right)\end{array}$ & $\begin{array}{c}\text { Effective heat } \\
\text { capacity } \\
\left(\mathrm{kJ} / \mathrm{m}^{2} \mathrm{~K}\right)\end{array}$ \\
\hline & 3.2 & 4.15 & 0.750 & 1.18 & 0.010 & 4.4 \\
\hline Angle $\left({ }^{\circ}\right)$ & 10 & 20 & 30 & 40 & 50 & 60 \\
\hline IAM for transversal angle & 1.01 & 1.02 & 1.04 & 1.04 & 0.99 & 0.90 \\
\hline IAM for longitudinal angle & 1.00 & 0.99 & 0.97 & 0.95 & 0.91 & 0.83 \\
\hline
\end{tabular}

The water tank model was based on a one-dimensional node approach. An immersed tank, containing domestic water and the outer tank, containing water as heat transfer fluid, were integrated. Domestic hot water tapping was modelled by ports at the bottom and top of the immersed tank. The space heating circuit was integrated via ports at the bottom and at a relative height of 0.67 of the water tank. The total water tank volume varied in simulation scenarios, while the immersed tank volume was fixed with $175 \mathrm{~L}$ to ensure sufficient hot water supply. Auxiliary heating was set to a power of $3 \mathrm{~kW}$, located at a relative tank height of 0.5 of the water tank.

The PCM units were modelled with differential equations for heat transfer as well as for enthalpies, solved by an explicit method. A one-dimensional node approach included vertical nodes for SAT composites, steel container, water in heat exchangers and insulation material. HTF flow distribution in PCM unit heat exchangers and initialization of SAT composite solidification was handled by the PCM unit controller model.

The annual space heating profile was loaded from a data file, which was based on hourly heating load calculation, resulting from the weather conditions during system demonstration in 2016. Three times a day (3:00 h, 9:00 h, and 21:00 h), calculated loads were discharged. The dependency of heating loads on solar irradiation and ambient temperature of a $130 \mathrm{~m}^{2}$ building in Passive House Standard [49] in Denmark has been previously determined by B. Johansen et al. [50] by simulation of a space heating system.

Daily DHW load profiles (see section 3.3) were implemented via time-dependent forcing functions.

Experimental HTF flow rates were used to simulate heat transfer via hydraulic circuits (Fig. 2). Initial temperature of the outer water tank volume was $45^{\circ} \mathrm{C}$. Inner tank volume, PCM units, and hydraulic components were set to $25{ }^{\circ} \mathrm{C}$. At the 
beginning of the year, one PCM unit was set to liquid, while the other units were set to solid state. To run system simulations close to application conditions, the following parameter approximations have been made:

- $\quad$ Phase change temperature interval of 55 to $58^{\circ} \mathrm{C}$

- Simulation time-step of one minute

- An observation period of five minutes before mode changes were executed

- Conditions for collector circuit stagnation: $\mathrm{T}_{\text {coll }}=130{ }^{\circ} \mathrm{C} ; \mathrm{T}_{\text {flow }}=100{ }^{\circ} \mathrm{C}$

Minute-based weather data from 2016, measured at the DTU climate station [51], was used for annual system simulation. The collector loop model and the behavior of the system controller were validated with experimental data from system operation in 2016. The annual, global irradiation on a horizontal plane was measured to $1010 \mathrm{kWh} / \mathrm{m}^{2}$, similar to the Danish reference year $\left(1038 \mathrm{kWh} / \mathrm{m}^{2}\right)$. All system simulations were conducted for a year (January $1^{\text {st }}-$ December $\left.31^{\text {st }}\right)$. Yearly energy balances of the collector circuit heat exchanger, water tank and the PCM heat storage were checked for each simulation.

\subsection{Model validation}

System tests have been conducted in accordance to the methodology used in functionality tests of the heat storage prototype [39]. Test data have been used to validate the TRNSYS component types used in the current study. For validation, experimental HTF flow rates were applied for system simulation. Resulting HTF temperatures during system tests and simulation were compared in each hydraulic circuit of the system (Fig. 2). Transferred heat, and the development of HTF temperatures were evaluated as follows:

- Collector circuit validation: Measurement data from March $17^{\text {th }}-$ April $28^{\text {th }} 2016$ were used. During this period the water tank and the PCM heat storage were daily charged with solar heat. Thus, HTF flow rates in the collector circuit and in the charging circuits varied in accordance to the mode $\mathrm{B}$ and the mode $\mathrm{C}$ (Fig. 2a and Fig. 2b). HTF temperatures close to the heat exchanger $\left(\mathrm{T}_{\text {coll flow }}\right)$ were compared. As for the annual system simulation, weather data of the DTU climate station, located in $150 \mathrm{~m}$ distance from the collector array, were applied. As in the prototype scenario (section 3.3), shading of the collector array by surrounding buildings and trees was considered implementing the angular obstruction heights with type 67.

- Water tank model validation: Measurement data from March $15^{\text {th }}-$ March $16^{\text {th }} 2016$ were used, where only the second day was evaluated to ensure equivalent temperature profiles in the tank. Charging was conducted via the collector

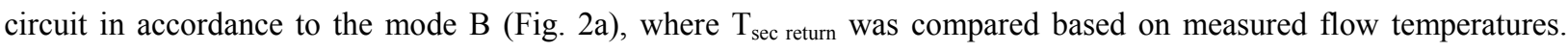
During discharging $\mathrm{T}_{\mathrm{SH}}$ and $\mathrm{T}_{\mathrm{DHW}}$ were compared. Pipe heat losses of each line were considered. DHW consumption, as described in the prototype scenario (section 3.3), was conducted with a flow rate of $5 \mathrm{~L} / \mathrm{min}$. For SH consumption (section 3.1) a HTF flow rate of $7 \mathrm{~L} /$ min was applied.

- $\quad$ PCM model validation: Measurement data of charge and discharge of a single PCM unit was used. HTF temperatures were compared in the return line of the PCM heat storage $\left(\mathrm{T}_{\mathrm{PCM} \text { return }}\right)$. HTF flow rates were approx. $16.5 \mathrm{~L} / \mathrm{min}$ during charging and $2 \mathrm{~L} / \mathrm{min}$ during discharging. Pipe heat losses were considered. For charging, heat was supplied from the 
solar collector circuit, which heated the HTF via the plate heat exchanger (Fig. 2b). Before charge and discharge the unit was in temperature equilibrium with the room. Charging stopped at $\mathrm{T}_{\mathrm{PCM} \text { return }}=88^{\circ} \mathrm{C}$. During discharging, cold HTF from the bottom of the water tank was heated from the PCM unit during SAT composite solidification (Fig. 2c).

\subsection{Investigated scenarios}

The prototype scenario was based on system demonstrator specifications (Table 2). Collector array shading at the prototype test facility, due to buildings and trees, was considered. A daily consumption of $113 \mathrm{~L}$ of hot water at $45^{\circ} \mathrm{C}$ and a cold water temperature of $10{ }^{\circ} \mathrm{C}$ was considered. User behaviour was simulated using three hot water draw-offs a day (7:00 h, 12:00 h, 19:00 h) with 1.545 kWh of heat each draw-off.

A scenario with optimized operation conditions was defined by neglecting the limitations of the system demonstrator. Component parameters were varied in accordance to Table 2. Ideal orientation of the collector array and no shading were considered, where an inclination of $70^{\circ}$ was found in sensitivity analysis of the system performance (section 4.3). Compact PCM heat storage design was assumed by increased insulation of the PCM units. A PCM unit size of $150 \mathrm{~L}$ was used for direct comparison with the prototype scenario, whereas a PCM unit size of $200 \mathrm{~L}$ was found to increase the annual system performance and was therefore applied for further scenario calculations. Reduced water tank heat losses were considered by reduced tank dimensions and increased insulation. A daily DHW consumption of $130 \mathrm{~L}$ at $45{ }^{\circ} \mathrm{C}$ was applied. With regards to the Danish code of practice [6], a cold water temperature of $10^{\circ} \mathrm{C}$ and increased use of hot water in the kitchen were assumed. $1.725 \mathrm{kWh}$ per draw-off, meaning $5.175 \mathrm{kWh}$ of daily loads were resulting, which was $15 \%$ higher than in the prototype scenario. The optimized scenario was applied to analyse the sensitivity of component sizing regarding the solar fraction of heat supply. Realistic variations of collector array aperture area and PCM volume were used to evaluate the performance potential of the system.

Finally, the demand-side flexibility of the system was investigated by simulating full storage charge from electricity at the beginning of the year, when almost no solar heat was available. This was realized by an initial temperature of $90{ }^{\circ} \mathrm{C}$ for both the PCM units and the outer volume of the water tank. The time duration of system operating without auxiliary heating was determined as well as the effect on annual coverage of heat demands including solar heat supply.

Table 2. Overview of applied parameters.

\begin{tabular}{|l|c|c|}
\hline \multirow{2}{*}{} & Prototype scenario & Optimized scenario \\
\cline { 2 - 3 } & \multicolumn{2}{|c|}{ Collector array } \\
\hline Aperture area: & $22.4 \mathrm{~m}^{2}$ & $9.6-28.8 \mathrm{~m}^{2}$ \\
\hline Inclination: & $45^{\circ}$ & $70^{\circ}$ \\
\hline Azimuth: & $12^{\circ}$ & $0^{\circ}$ \\
\hline Shading: & on & $0.15-2.8 \mathrm{~m}^{3}$ \\
\hline & \multicolumn{2}{|c|}{ PCM heat storage } \\
\hline Volume: & $0.6 \mathrm{~m}^{3}$ & $0.15 ; 0.5 ; 0.15 \mathrm{~m}$ \\
\hline $\begin{array}{l}\text { Insulation thickness: } \\
\text { (top; sides; bottom) }\end{array}$ & $0.1 ; 0.1 ; 0.1 \mathrm{~m}$ & \\
\hline
\end{tabular}




\begin{tabular}{|l|c|c|}
\hline $\begin{array}{l}\text { Thermal conductivity } \\
\text { of insulation: }\end{array}$ & $0.04 \mathrm{~W} / \mathrm{mK}$ & $0.02 \mathrm{~W} / \mathrm{mK}$ \\
\hline Unit size: & $150 \mathrm{~L}$ & $150 / 200 \mathrm{~L}$ \\
\hline & \multicolumn{2}{|c|}{ Water tank } \\
\hline Volume: & $0.74 \mathrm{~m}^{3}$ & $0.6 / 1 \mathrm{~m}^{3}$ \\
\hline Height: & $1.6 \mathrm{~m}$ & $1.6 / 2 \mathrm{~m}$ \\
\hline $\begin{array}{l}\text { Heat loss coefficient: } \\
\text { (top; mantle; bottom) }\end{array}$ & $4.5 ; 2 ; 0.25 \mathrm{~W} / \mathrm{K}$ & $1 ; 1 ; 0.25 / 1 ; 2 ; 0.25 \mathrm{~W} / \mathrm{K}$ \\
\hline & \multicolumn{2}{|c|}{ Annual heat demand } \\
\hline Space heating: & $2031 \mathrm{kWh}$ & $2031 \mathrm{kWh}$ \\
\hline Hot water: & $1692 \mathrm{kWh}$ & $1946 \mathrm{kWh}$ \\
\hline
\end{tabular}

\subsection{Performance evaluation}

Simulation results were evaluated by yearly and monthly energy balances, calculated by periodic integration of heat transfer rates in the hydraulic circuits. The following indicators were used to analyse system performance:

$$
\begin{aligned}
& Q_{\text {solar }}(k W h)=\int\left(\dot{Q}_{S H}+\dot{Q}_{D H W}-\dot{Q}_{a u x}\right) * d t \\
& S F \text { or } R E F(\%)=\left[1-\frac{\int\left(\dot{Q}_{a u x}\right) * d t}{\int\left(\dot{Q}_{S H}+\dot{Q}_{D H W}\right) * d t}\right] * 100
\end{aligned}
$$

where the net utilized solar heat $\left(Q_{\text {solar }}\right)$ is the sum of the domestic hot water and space heating minus auxiliary energy use. The solar fraction (SF) was calculated in scenarios without and the renewable energy fraction (REF) in scenarios with full storage charge at the beginning of the year. Both indicators were calculated as the fraction of annual net utilized solar energy divided by SH and DHW demand. $Q_{\text {solar }}$, SF and REF were determined at the water tank.

The specific solar yield per square meter aperture area $\left(q_{\text {coll }}\right)$ of the collector circuit and the number of storage cycles per year $\left(N_{c y c l e}\right)$ of water tank and PCM heat storage were calculated to analyse the sensitivity of component sizing:

$$
\begin{aligned}
N_{\text {cycle }} & =\frac{\int\left(\dot{Q}_{\text {out }}\right) * d t}{C} \\
q_{\text {coll }}\left(\frac{k W h}{m^{2}}\right) & =\frac{\int\left(\dot{Q}_{\text {coll }}\right) * d t}{A}
\end{aligned}
$$

where the capacity (C) of single PCM unit, containing 150 L of SAT composite, was considered with $27 \mathrm{kWh}$ [45]. PCM heat storage capacities were scaled according to the set volumes in the calculation. Water tank capacities were calculated to be $34 \mathrm{kWh}$ for $0.6 \mathrm{~m}^{3}, 45 \mathrm{kWh}$ for $0.8 \mathrm{~m}^{3}$ and $57 \mathrm{kWh}$ for $1 \mathrm{~m}^{3}$. For heat draw $\left(\dot{Q}_{\text {out }}\right)$, heat supply from the PCM to the water tank, respectively from the water tank to the SH and DHW circuits were considered. 


\section{Results and discussion}

\subsection{Model validation}

Table 3 presents a comparison of measured and simulated heat transfer in collector circuit, water tank and PCM heat storage. All component models were found to be valid with minor deviations:

- Solar yield $\left(\mathrm{Q}_{\text {coll }}\right)$ was $1.9 \%$ higher in the simulation than during the testing period from March $17^{\text {th }}-$ April $28^{\text {th }} 2016$. This period is crucial for annual system performance because solar heat was directly utilized for heat supply via the water tank and the PCM units were charged.

- Water tank simulation resulted in $1.7 \%$ higher charge $\left(Q_{\text {charge}}\right)$ during March $15^{\text {th }}-$ March $16^{\text {th }}$. Simulated $\mathrm{SH}$ consumption $\left(\mathrm{Q}_{\mathrm{SH}}\right)$ was 1.9\% lower, and simulated DHW consumption ( $\mathrm{Q}_{\mathrm{DHW}}$ ) was 1.5\% higher than in measurements. Measured $\mathrm{Q}_{\mathrm{DHW}}$ and therefore also simulated $\mathrm{Q}_{\mathrm{SH}}$ deviated from the prototype scenario. This is not the case in later scenario calculation, where time-dependent forcing functions were used.

- Simulated PCM unit charge ( $\mathrm{Q}_{\mathrm{PCM}}$ charge $)$ was only $0.6 \%$ lower than in measurements. Measured $\mathrm{QPCM}_{\mathrm{PCM}}$ charge and therefore also simulated $\mathrm{Q}_{\mathrm{PCM}}$ was higher than in functionality tests [45], because initial temperatures of the PCM unit were lower. Simulated PCM unit discharge ( $\mathrm{Q}_{\mathrm{PCM} \text { discharge }}$ ) was $2.6 \%$ higher than in measurements, therefore less heat remained in the PCM unit when discharge stopped.

Table 3. Simulated and measured heat transfer in collector circuit, water tank and PCM heat storage.

\begin{tabular}{|c|c|c|c|c|}
\hline & $\begin{array}{c}\text { Measurement } \\
(\mathbf{k W h})\end{array}$ & $\begin{array}{c}\text { Simulation } \\
(\mathbf{k W h})\end{array}$ & $\begin{array}{c}\text { Deviation } \\
(\mathbf{k W h})\end{array}$ & $\begin{array}{c}\text { Deviation } \\
(\mathbf{\%})\end{array}$ \\
\hline $\begin{array}{c}\text { Qcoll }_{\text {March 17th }}-\text { April 28 } \\
\text { th } 2016)\end{array}$ & 1146 & 1168 & 22 & 1.9 \\
\hline$Q_{\text {charge }}$ & 25.2 & 25.6 & 0.4 & 1.7 \\
\hline QSH $_{\text {QDHW }}$ & 10.4 & 10.2 & 0.2 & 1.9 \\
\hline QPCM charge & 4.76 & 4.83 & 0.07 & 1.5 \\
\hline QPCM discharge & 28.09 & 27.91 & 0.18 & 0.6 \\
\hline
\end{tabular}

Fig. 3 presents a comparison of the development of measured and simulated $\mathrm{T}_{\text {coll flow }}$ and $\mathrm{Q}_{\text {coll }}$ from the March $30^{\text {th }}-$ April $1^{\text {st }}$ 2016. During each day, water tank charging before noon was followed by PCM heat storage charging with a varying number of PCM units. HTF temperatures fluctuated due to changes of solar irradiance as well as during mode changes. Measured and simulated $\mathrm{T}_{\text {coll flow }}$ approximately matched. Minor deviations in morning and evening hours corresponded to periods with partial shading of the collector array. Because of the relatively large collector area partial shading occurred in tests, this could not be considered in the shading model. Overall, developments of $\mathrm{T}_{\text {coll flow }}$ and $\mathrm{Q}_{\text {coll }}$ showed a high degree of similarity. 


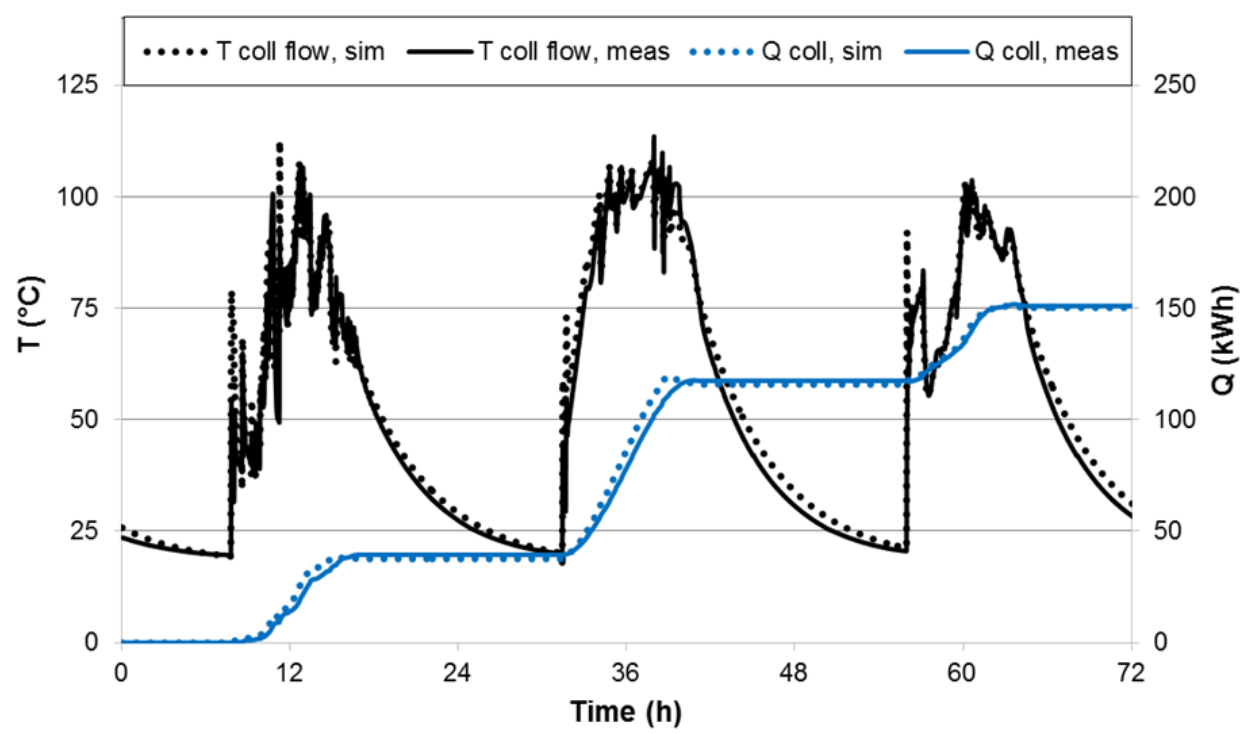

Fig. 3. Collector circuit validation.

Fig. 4 presents results of water tank model validation with experimental data from March $16^{\text {th }} 2016$. Charging took place in two periods from approximately 9:00 h -11:00 h and from 15:00 h-14:00 h. As presented in Fig. 4a, $T_{\text {sec return }}$ was slightly lower at the beginning and slightly higher towards the end of each charging period, in comparison to measured values. Measurement values in between those periods are resulting from PCM charging, which was employed via the same hydraulic line. Overall, $\mathrm{T}_{\text {sec return }}$ had a high degree of similarity and the development of $\mathrm{Q}_{\text {charge }}$ matched. As presented in Fig. $4 \mathrm{~b}, \mathrm{~T}_{\mathrm{SH}}$ matched at the beginning and at the end of SH consumption. Deviations during cool-down of the pipework did not compromise the simulation. $\mathrm{Q}_{\mathrm{SH}}$ had a sufficient degree of similarity. As presented in Fig. 4c, DHW consumption also started with precise HTF temperatures. Towards the end of the first draw-off $\mathrm{T}_{\mathrm{DHW}}$ was approximately $3 \mathrm{~K}$ lower and towards the end of the second draw-off approximately $3 \mathrm{~K}$ lower than in tests, whereas values matched during the third draw-off. This is considered as sufficient degree of similarity, because the development of $\mathrm{Q}_{\mathrm{DHW}}$ approximately matched.

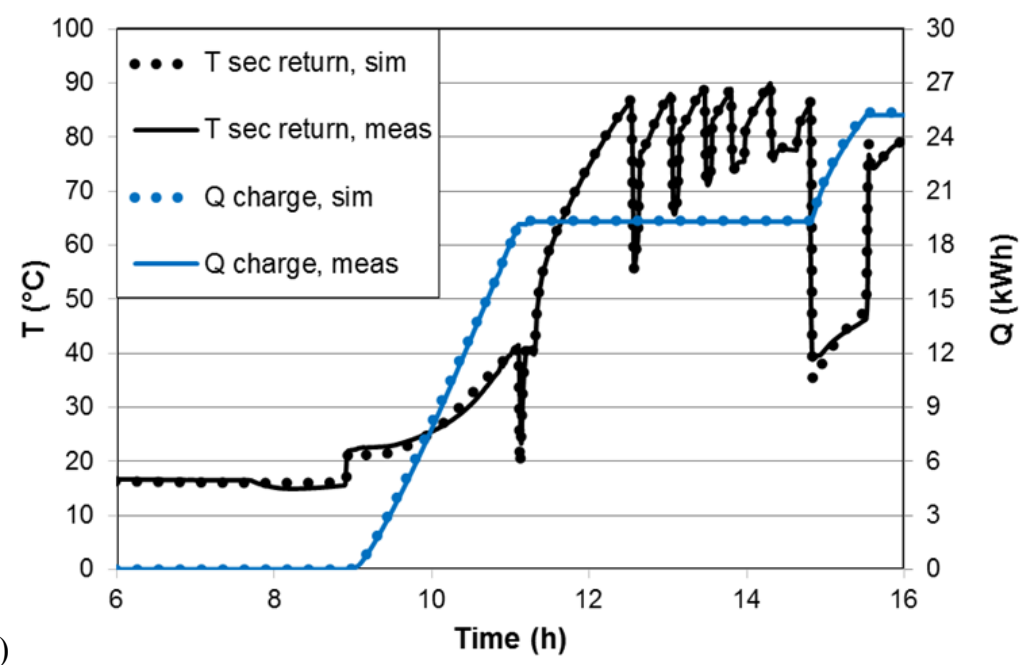




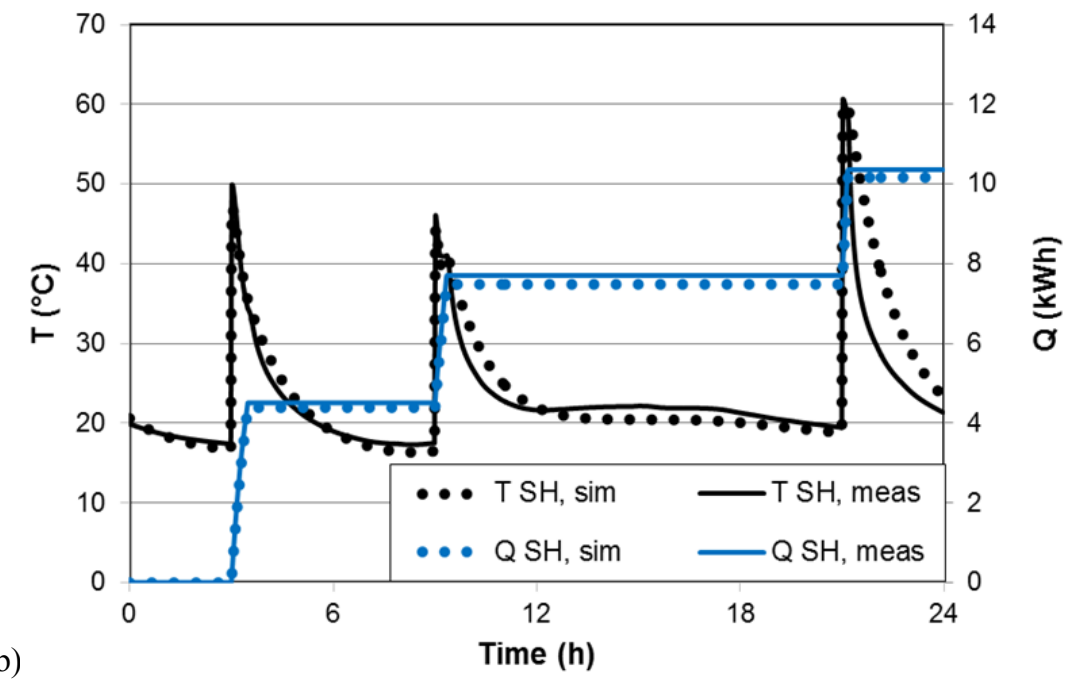

b)

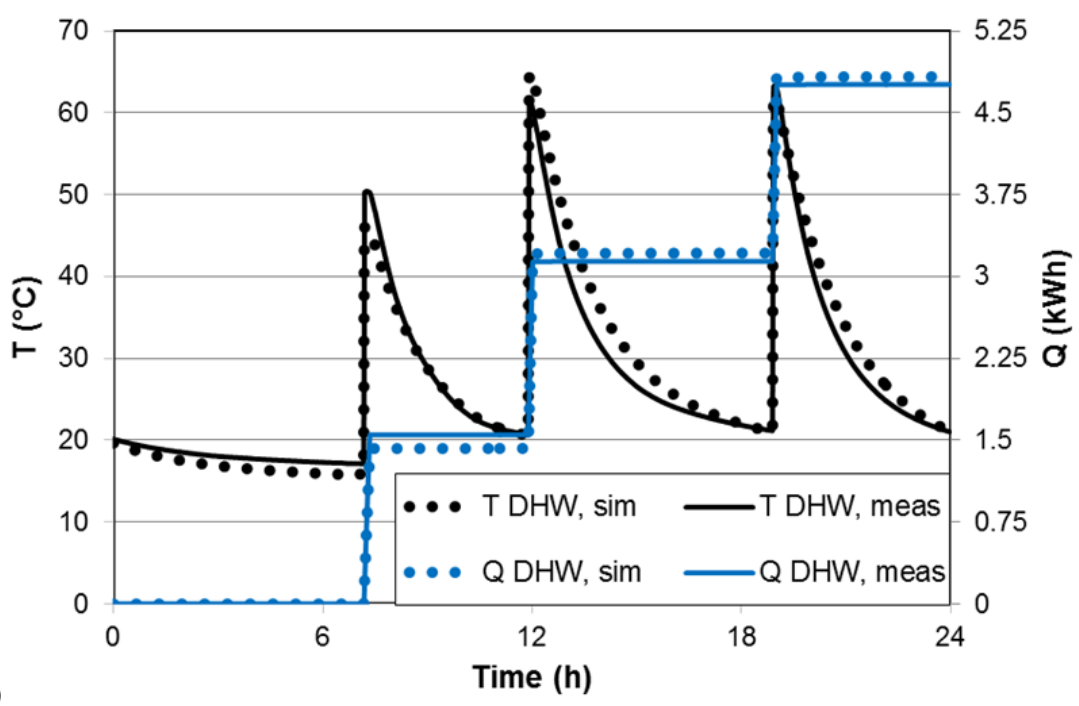

Fig. 4. Water tank model validation: a) Charging circuit; b) SH consumption; c) DHW consumption.

Fig. 5a presents a comparison of the developments of $\mathrm{T}_{\mathrm{PCM}}$ return and of $\mathrm{Q}_{\mathrm{PCM}}$ charge. $\mathrm{T}_{\mathrm{PCM} \text { return }}$ had a high degree of similarity, whereas simulated $\mathrm{Q}_{\mathrm{PCM}}$ charge rose with time delay. The developments of $\mathrm{T}_{\mathrm{PCM} \text { return }}$ and of $\mathrm{Q}_{\mathrm{PCM} \text { discharge }}$ are shown in Fig. 5b. Simulated $\mathrm{T}_{\mathrm{PCM} \text { return }}$ deviated, whereas $\mathrm{Q}_{\mathrm{PCM} \text { discharge }}$ had a high degree of similarity. The described deviations are considered to be the result of idealized modelling of SAT composite phase change, where a temperature interval of $55-58^{\circ} \mathrm{C}$ was applied. 


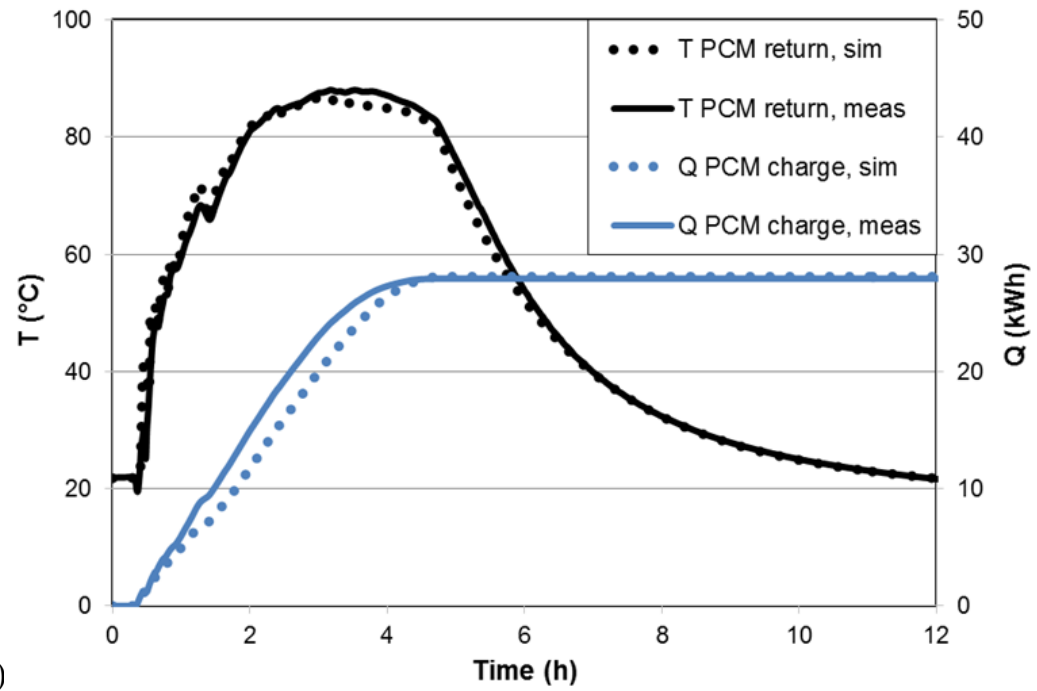

a)

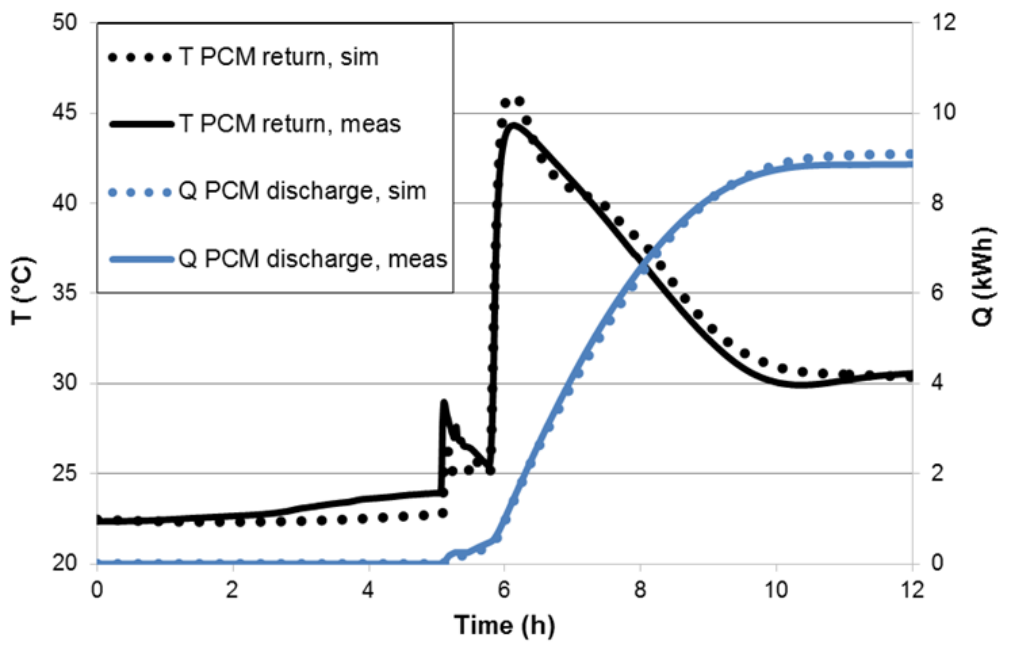

Fig. 5. PCM heat storage model validation: a) Charge; b) Discharge.

\subsection{Annual system performance}

The system performance was calculated for the prototype scenario with a water volume of $0.74 \mathrm{~m}^{3}$ and for the optimized scenario with $\mathrm{V}_{\text {water }}=0.6 \mathrm{~m}^{3}$. Results are shown in Table 4 and in Table 5. In both scenarios the DHW demand was fully covered by solar heat from April to September (indicated by a solar fraction of 100\%) due to the relatively large collector array $\left(\mathrm{A}=22.4 \mathrm{~m}^{2}\right)$. During this period the water tank was directly heated by the collector array and also collector circuit stagnation occurred. From October to March space heating caused higher heat demand, which was partly covered by heat transfer from the PCM heat storage. The electrical heater covered the missing load by heating the water tank. With the prototype configuration the PCM store was utilized during four months, while with the optimized configuration the PCM store was used during the whole heating season. 
Table 4. Heat supply in the prototype and in the optimized scenario with $\mathrm{A}=22.4 \mathrm{~m}^{2}$ and $\mathrm{V}_{\mathrm{PCM}}=0.6 \mathrm{~m}^{3}$ with 4 units of $150 \mathrm{~L}$.

\begin{tabular}{|c|c|c|c|c|c|c|c|c|c|}
\hline \multirow{2}{*}{} & $\begin{array}{c}\text { SH } \\
\mathbf{k W h}\end{array}$ & \multicolumn{2}{|c|}{$\begin{array}{c}\text { DHW } \\
\mathbf{( k W h}\end{array}$} & \multicolumn{2}{c|}{$\begin{array}{c}\text { Qaux } \\
\mathbf{k W h}\end{array}$} & \multicolumn{2}{c|}{$\begin{array}{c}\text { Qsolar } \\
\text { (kWh) }\end{array}$} & \multicolumn{2}{c|}{$\begin{array}{c}\text { SF } \\
\text { (\%) }\end{array}$} \\
\cline { 2 - 11 } & $\begin{array}{c}\text { Both } \\
\text { scenarios }\end{array}$ & $\begin{array}{c}\text { Prototype } \\
\text { scenario }\end{array}$ & $\begin{array}{c}\text { Optimized } \\
\text { scenario }\end{array}$ & $\begin{array}{c}\text { Prototype } \\
\text { scenario }\end{array}$ & $\begin{array}{c}\text { Optimized } \\
\text { scenario }\end{array}$ & $\begin{array}{c}\text { Prototype } \\
\text { scenario }\end{array}$ & $\begin{array}{c}\text { Optimized } \\
\text { scenario }\end{array}$ & $\begin{array}{c}\text { Prototype } \\
\text { scenario }\end{array}$ & $\begin{array}{c}\text { Optimized } \\
\text { scenario }\end{array}$ \\
\hline January & 512 & 143 & 165 & 518 & 454 & 137 & 211 & $21 \%$ & $31 \%$ \\
\hline February & 344 & 129 & 149 & 287 & 237 & 186 & 259 & $39 \%$ & $52 \%$ \\
\hline March & 324 & 143 & 165 & 151 & 137 & 316 & 354 & $68 \%$ & $72 \%$ \\
\hline April & 0 & 139 & 160 & 0 & 0 & 139 & 160 & $100 \%$ & $100 \%$ \\
\hline May & 0 & 144 & 166 & 0 & 0 & 144 & 166 & $100 \%$ & $100 \%$ \\
\hline June & 0 & 140 & 161 & 0 & 0 & 140 & 161 & $100 \%$ & $100 \%$ \\
\hline July & 0 & 144 & 166 & 0 & 0 & 144 & 166 & $100 \%$ & $100 \%$ \\
\hline August & 0 & 144 & 166 & 0 & 0 & 144 & 166 & $100 \%$ & $100 \%$ \\
\hline September & 0 & 140 & 161 & 0 & 0 & 140 & 161 & $100 \%$ & $100 \%$ \\
\hline October & 173 & 143 & 165 & 96 & 23 & 220 & 319 & $69 \%$ & $93 \%$ \\
\hline November & 321 & 139 & 160 & 171 & 55 & 289 & 425 & $63 \%$ & $88 \%$ \\
\hline December & 358 & 143 & 165 & 400 & 320 & 101 & 203 & $20 \%$ & $38 \%$ \\
\hline Annual & $\mathbf{2 0 3 1}$ & 1692 & 1946 & 1623 & 1227 & $\mathbf{2 1 0 0}$ & $\mathbf{2 7 5 0}$ & $\mathbf{5 6 \%}$ & $\mathbf{6 9 \%}$ \\
\hline
\end{tabular}

Table 5. Heat transfer in the prototype and in the optimized scenario with $\mathrm{A}=22.4 \mathrm{~m}^{2}$ and $\mathrm{V}_{\mathrm{PCM}}=0.6 \mathrm{~m}^{3}$ with 4 units of $150 \mathrm{~L}$.

\begin{tabular}{|c|c|c|c|c|c|c|c|c|c|c|}
\hline \multirow{2}{*}{} & \multicolumn{2}{|c|}{$\begin{array}{c}Q_{\text {coll }} \\
(\mathbf{k W h})\end{array}$} & \multicolumn{2}{c|}{$\begin{array}{c}\text { qcoll } \\
\left(\mathbf{k W h} / \mathbf{m}^{2}\right)\end{array}$} & \multicolumn{2}{c|}{$\begin{array}{c}\text { Buffer charge } \\
(\mathbf{k W h})\end{array}$} & \multicolumn{2}{c|}{$\begin{array}{c}\text { PCM charge } \\
\text { (kWh) }\end{array}$} & \multicolumn{2}{c|}{$\begin{array}{c}\text { PCM to buffer } \\
\text { (kWh) }\end{array}$} \\
\cline { 2 - 14 } & $\begin{array}{c}\text { Prototype } \\
\text { scenario }\end{array}$ & $\begin{array}{c}\text { Optimized } \\
\text { scenario }\end{array}$ & $\begin{array}{c}\text { Prototype } \\
\text { scenario }\end{array}$ & $\begin{array}{c}\text { Optimized } \\
\text { scenario }\end{array}$ & $\begin{array}{c}\text { Prototype } \\
\text { scenario }\end{array}$ & $\begin{array}{c}\text { Optimized } \\
\text { scenario }\end{array}$ & $\begin{array}{c}\text { Prototype } \\
\text { scenario }\end{array}$ & $\begin{array}{c}\text { Optimized } \\
\text { scenario }\end{array}$ & $\begin{array}{c}\text { Prototype } \\
\text { scenario }\end{array}$ & $\begin{array}{c}\text { Optimized } \\
\text { scenario }\end{array}$ \\
\hline January & 192 & 235 & 9 & 11 & 157 & 136 & 32 & 94 & 14 & 89 \\
\hline February & 259 & 298 & 12 & 13 & 181 & 175 & 71 & 116 & 40 & 98 \\
\hline March & 547 & 531 & 24 & 24 & 262 & 244 & 269 & 275 & 106 & 150 \\
\hline April & 548 & 297 & 24 & 13 & 200 & 221 & 322 & 55 & 6 & 4 \\
\hline May & 769 & 322 & 34 & 14 & 282 & 239 & 440 & 53 & 0 & 0 \\
\hline June & 681 & 298 & 30 & 13 & 233 & 224 & 405 & 47 & 0 & 0 \\
\hline July & 635 & 305 & 28 & 14 & 217 & 227 & 380 & 51 & 0 & 0 \\
\hline August & 685 & 308 & 31 & 14 & 240 & 229 & 409 & 53 & 0 & 0 \\
\hline September & 665 & 292 & 30 & 13 & 231 & 217 & 393 & 48 & 0 & 0 \\
\hline October & 360 & 348 & 16 & 16 & 191 & 198 & 156 & 139 & 61 & 127 \\
\hline November & 350 & 437 & 16 & 20 & 274 & 218 & 67 & 209 & 39 & 224 \\
\hline December & 153 & 212 & 7 & 9 & 141 & 130 & 8 & 77 & 0 & 83 \\
\hline Annual & $\mathbf{5 8 4 4}$ & $\mathbf{3 8 8 4}$ & $\mathbf{2 6 1}$ & $\mathbf{1 7 3}$ & $\mathbf{2 6 0 8}$ & $\mathbf{2 4 5 9}$ & $\mathbf{2 9 5 3}$ & $\mathbf{1 2 1 6}$ & $\mathbf{2 6 5}$ & $\mathbf{7 7 5}$ \\
\hline
\end{tabular}

An annual SF of $56 \%$ was calculated for the prototype scenario. Although higher DHW demand was simulated in the optimized scenario (Table 3), the annual SF increased to $69 \%$.

Improved PCM unit insulation, optimized collector array tilt (see also section 4.3) and a smaller water tank with improved insulation resulted in significantly better annual system performance (Table 5). As a consequence of the reduced system heat losses, the specific yield of the solar collector $\left(q_{\text {coll }}\right)$ decreased from 261 to $173 \mathrm{kWh} / \mathrm{m}^{2}$. Direct charge of the 
water tank (buffer charge) decreased slightly from 2608 to $2459 \mathrm{kWh}$, while PCM charge dropped from 2953 to $1216 \mathrm{kWh}$. On the contrary, in the prototype scenario only $265 \mathrm{kWh}$ of stored heat in the PCM units was transferred to the water tank when there was a heat demand. The transferred heat was increased to $775 \mathrm{kWh}$ in the optimized scenario. This means an increase of utilized storage cycles per year from 2.5 to 7.2. The number of annual storage cycles $\left(\mathrm{N}_{\text {cycle }}\right)$ of the water tank increased from 82 to 116 , due to decreased size and higher DHW demand. The PCM store was mainly utilized for heat supply from January to March and in October and November.

\subsection{System performance sensitivity}

The influences of collector area, PCM volume (200 L units) and water tank volume on the solar fraction are shown in Table 6. The investigated SF (equation 2) ranged from $47.5 \%\left(\mathrm{~V}_{\text {water }}=0.6 \mathrm{~m}^{3}, \mathrm{~A}=9.6 \mathrm{~m}^{2} ; \mathrm{V}_{\mathrm{PCM}}=0.2 \mathrm{~m}^{3}\right)$ to $76.7 \%$ $\left(\mathrm{V}_{\text {water }}=1 \mathrm{~m}^{3}, \mathrm{~A}=25.6 \mathrm{~m}^{2} ; \mathrm{V}_{\mathrm{PCM}}=2.8 \mathrm{~m}^{3}\right)$. SF changed moderately (about $4 \%$ ) by variation of $\mathrm{V}_{\mathrm{PCM}}$. Collector area increase from $A=9.6 \mathrm{~m}^{2}$ to $\mathrm{A}=25.6 \mathrm{~m}^{2}$ increased $\mathrm{SF}$ by approximately $25 \%$ points throughout all storage sizes. The performance difference was most significant between $A=9.6 \mathrm{~m}^{2}$ and $A=12.8 \mathrm{~m}^{2}$ respectively, between 3 and 4 collector panels. For $\mathrm{A}=9.6 \mathrm{~m}^{2}$ the maximal number of PCM units in use was identified to $9\left(1.8 \mathrm{~m}^{3}\right)$, smaller collector areas were therefore not included in evaluations.

With a water tank volume of $1 \mathrm{~m}^{3}$, aperture areas above $12.8 \mathrm{~m}^{2}$ were required to increase the solar heat supply. Otherwise, the solar fraction of heat supply was lower than with a water tank volume of $0.6 \mathrm{~m} 3$ (negative values in Table 5). This means that the system was not able to compensate additional storage heat losses with smaller collector arrays. Thus, it was found that bigger water tanks would be only beneficial when its heat losses could be reduced.

Table 6. Parametric study on SF of the optimized scenario:

\begin{tabular}{|c|c|c|c|c|c|}
\hline $\mathbf{V}_{\mathbf{P C M}}\left(\mathbf{m}^{\mathbf{3}}\right)$ & $\mathbf{0 . 2}$ & $\mathbf{0 . 4}$ & $\mathbf{1}$ & $\mathbf{2}$ & $\mathbf{2 . 8}$ \\
\hline No. of units & $\mathbf{1}$ & $\mathbf{2}$ & $\mathbf{5}$ & $\mathbf{1 0}$ & $\mathbf{1 4}$ \\
\hline \multirow{2}{*}{$\mathrm{A}\left(\mathrm{m}^{2}\right)$} & \multicolumn{5}{|c|}{$\mathrm{SF}(\%)$} \\
& with $0.6 \mathrm{~m}^{3}$ water \\
\hline 9.6 & 47.5 & 47.9 & 49.1 & 50.3 & 50.3 \\
12.8 & 54.8 & 55.2 & 56.5 & 57.8 & 59.3 \\
16 & 60.2 & 60.4 & 62.2 & 63.7 & 64.3 \\
19.2 & 64.8 & 64.8 & 66.2 & 67.7 & 68.5 \\
22.4 & 68.9 & 68.9 & 71.2 & 72 & 72.7 \\
25.6 & 72.7 & 73.8 & 74.2 & 75.1 & 76.1 \\
\cline { 2 - 6 } & \multicolumn{5}{|c|}{ Change of SF (\%) } \\
9.6 & -0.4 & -0.3 & -0.5 & -0.7 & -0.7 \\
12.8 & 0.0 & -0.1 & -0.2 & -0.1 & -0.3 \\
16 & 0.5 & 0.5 & 0.1 & 0.3 & 0.3 \\
19.2 & 1.5 & 1.3 & 1.1 & 0.9 & 0.8 \\
22.4 & 2.1 & 2.2 & 1.0 & 1.0 & 0.9 \\
25.6 & 1.5 & 0.6 & 0.7 & 0.6 & 0.6 \\
\hline
\end{tabular}

Fig. 6 shows the influence of PCM heat storage and collector area specifications on the annual net utilized solar heat (equation 1). As reference, a scenario was defined as: $A=16 \mathrm{~m}^{2}, \mathrm{I}=70^{\circ}, \mathrm{V}_{\mathrm{PCM}}=1 \mathrm{~m}^{3}$ and $200 \mathrm{~L}$ PCM units. Collector array sizing had the highest impact on solar heat supply, where relative changes of $+/-20 \%$ were calculated with a $60 \%$ larger 
and respectively $40 \%$ smaller aperture area. A collector inclination of $70^{\circ}$ was found as optimum. A tilt-change of $+/-20^{\circ}$ reduced solar heat utilization by $3 \%$. Relatively small changes of net utilized solar heat $(+/-3 \%)$ were observed for PCM heat storage sizes $180 \%$ larger and $80 \%$ smaller. A halving of PCM unit size revealed a significant effect $(-2.6 \%)$, while with units of $333 \mathrm{~L}$ the solar heat supply increased by only $0.5 \%$. Therefore, it was found a PCM unit size of $200 \mathrm{~L}$ or larger should be applied. In the reference scenario, full storage charge at the beginning of the year increased the solar heat supply by $5 \%$. An increase of $14 \%$ was observed with $\mathrm{V}_{\mathrm{PCM}}=2.8 \mathrm{~m}^{3}$.

It was not possible to simulate heat transfer in between the units. Thus, increased insulation of PCM units (Table 2) was set to model an optimized, stacked storage of several units with a lower surface-volume ratio. No scaling factor was used. However, the conducted sensitivity analysis is correct assuming smaller PCM volumes can be obtained with more compact unit design. For example, cylindrical prototype units [40] were reported with a smaller surface-volume ratio than flat plate prototype units [45].

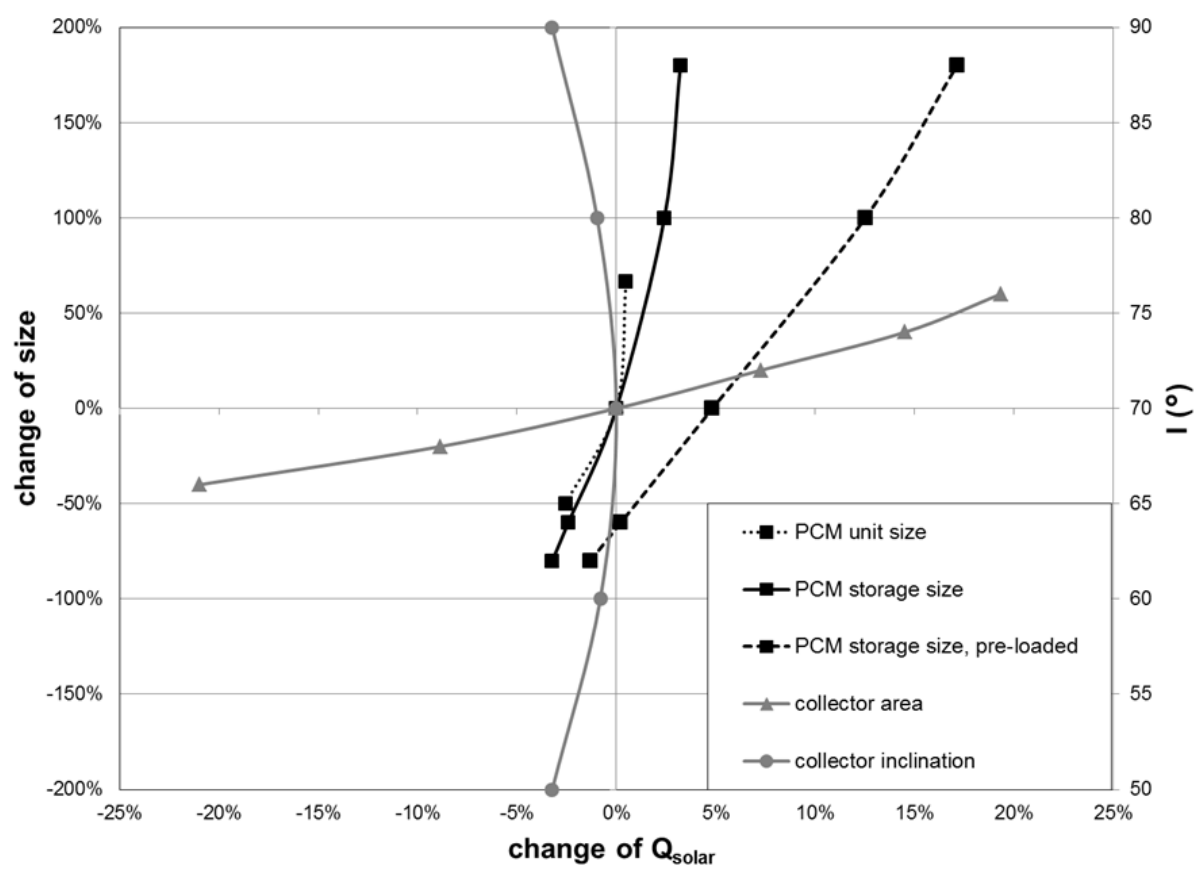

Fig. 6. Annual net utilized solar heat in dependency of PCM heat storage and collector array parameters.

\subsection{PCM heat storage}

Fig. 7 a shows the heat transfer from the PCM units to water tanks of 0.6 and $1 \mathrm{~m}^{3}$ in dependency of PCM volume and collector area. Increased water tank size reduced the gain from the PCM units but did not significantly change SF (Table 6). A tank volume of $0.4 \mathrm{~m}^{3}$ decreased the heat transfer to the same extent as a $6.4 \mathrm{~m}^{2}$ smaller collector aperture area. Then, the annual PCM heat supply with $\mathrm{A}=22.4 \mathrm{~m}^{2}$ and $\mathrm{V}_{\mathrm{PCM}}=0.2 \mathrm{~m}^{3}$ dropped by $200 \mathrm{kWh}$, illustrating that the annual number of storage utilization cycles $\mathrm{N}_{\text {cycle }}$ (equation 3) was reduced from 15.6 to 10 . For $\mathrm{V}_{\mathrm{PCM}}=2.8 \mathrm{~m}^{3}$ heat supply dropped by 260 $\mathrm{kWh}$, respectively $\mathrm{N}_{\text {cycle }}$ was reduced from 2 to 1.5. Thus, heat storage utilizing stable supercooling of SAT is more attractive for a solar combi-system with small water tanks (see also section 4.5). 
Fig. $7 \mathrm{~b}$ shows that initial full-charge of heat stores increased PCM heat supply by $120-175 \mathrm{kWh}$ for $\mathrm{V}_{\mathrm{PCM}}=1 \mathrm{~m}^{3}$; $240-300 \mathrm{kWh}$ for $\mathrm{V}_{\mathrm{PCM}}=2 \mathrm{~m}^{3}$ and $340-360 \mathrm{kWh}$ for $\mathrm{V}_{\mathrm{PCM}}=2.8 \mathrm{~m}^{3}$. As investigated by Englmair et al. [45] a minimal PCM temperature above $50{ }^{\circ} \mathrm{C}$ is needed when heat is discharged during SAT composite solidification. Thus, only $80 \%$ of heat of fusion could be used. The maximal discharge-to-charge ratio would be 0.91 , assuming full utilization of stored sensible heat during discharge from $90{ }^{\circ} \mathrm{C}$ in liquid SAT composite state (55\% of charge) and $80 \%$ heat of fusion (36\% of charge). Calculated ratios ranged from 1.17 with PCM volumes below $1 \mathrm{~m}^{3}$ to 0.7 with volumes of $2.8 \mathrm{~m}^{3}$. This indicates that 1-2 PCM units were additionally charged by solar heat at the beginning of the year, due to higher PCM temperatures. Larger PCM volumes provided heat over a longer period, resulting in sensible heat losses.

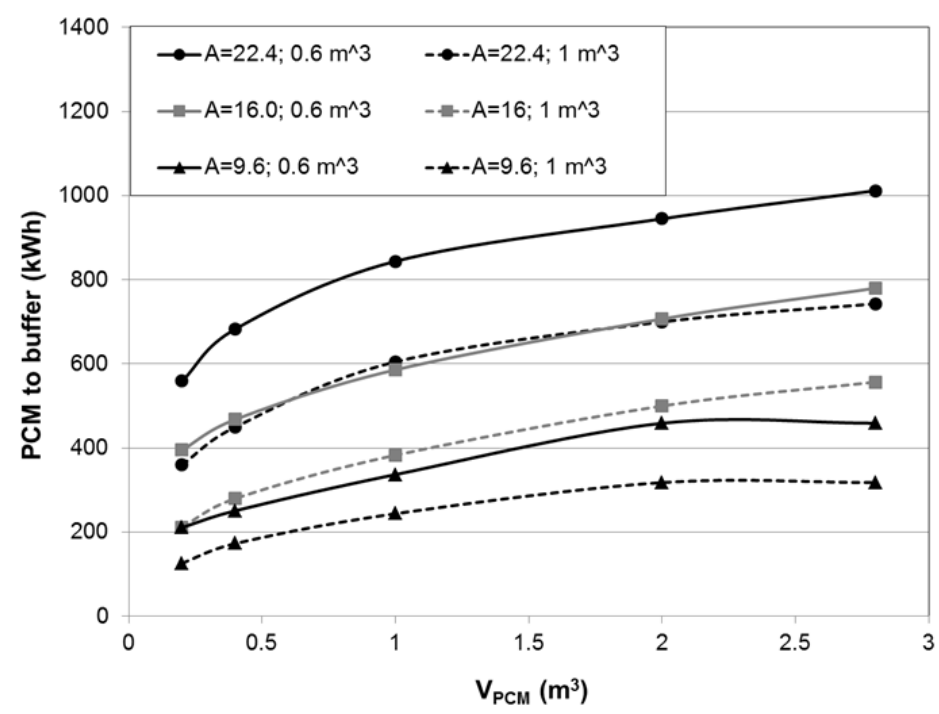

a)

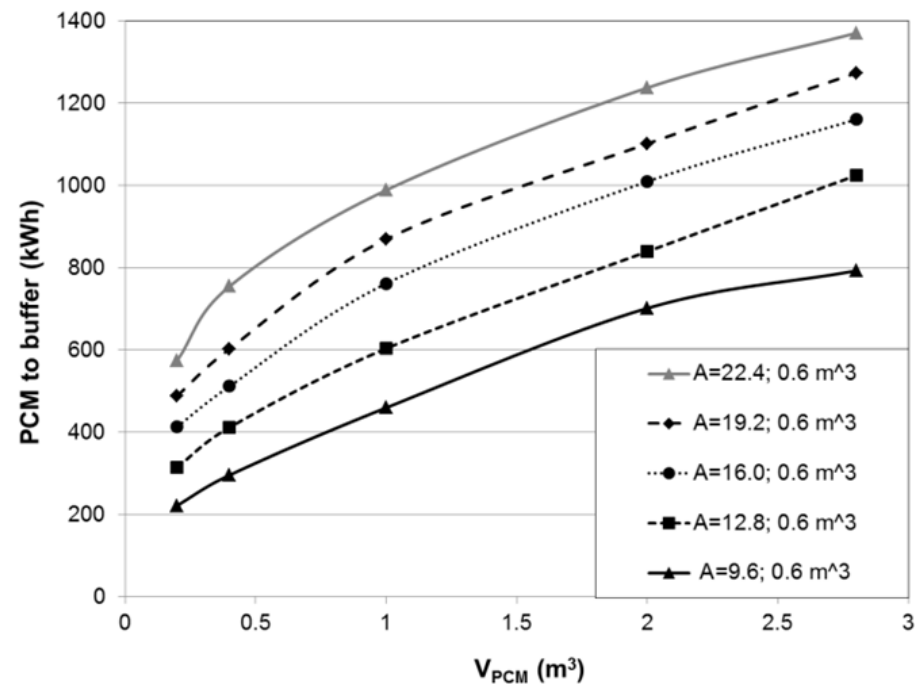

Fig. 7. Heat transfer from the PCM heat storage to the water tank: a) With variation of water tank volume;

b) With initial full-charge of stores. 


\subsection{System sizing aspects}

A full charged water tank of $0.6 \mathrm{~m}^{3}$ provided sufficient storage capacity for SH and DHW supply for at least one winter day. The PCM heat storage and the collector circuit are considered to cause the largest share of system costs, accordingly their sizing is pivotal.

Specific solar yields (equation 4; Fig. 8) ranged from $134 \mathrm{kWh} / \mathrm{m}^{2}\left(\mathrm{~A}=28.8 \mathrm{~m}^{2} ; \mathrm{V}_{\mathrm{PCM}}=0.2 \mathrm{~m}^{3}\right)$ to $330 \mathrm{kWh} / \mathrm{m}^{2}$ $\left(A=9.6 \mathrm{~m}^{2} ; V_{\mathrm{PCM}}=2 \mathrm{~m}^{3}\right)$. Increase of PCM volume increased the solar yield. Highest impact was identified for $\mathrm{A}=12.8 \mathrm{~m}^{2}$, whereas additional $104 \mathrm{kWh} / \mathrm{m}^{2}$, respectively $1331 \mathrm{kWh}$ of heat have been yielded annually with $\mathrm{V}_{\mathrm{PCM}}=2.8 \mathrm{~m}^{3}$ in comparison to $\mathrm{V}_{\mathrm{PCM}}=0.2 \mathrm{~m}^{3}$. The impact of $\mathrm{V}_{\mathrm{PCM}}$ on the solar yield was lower with larger collector arrays.

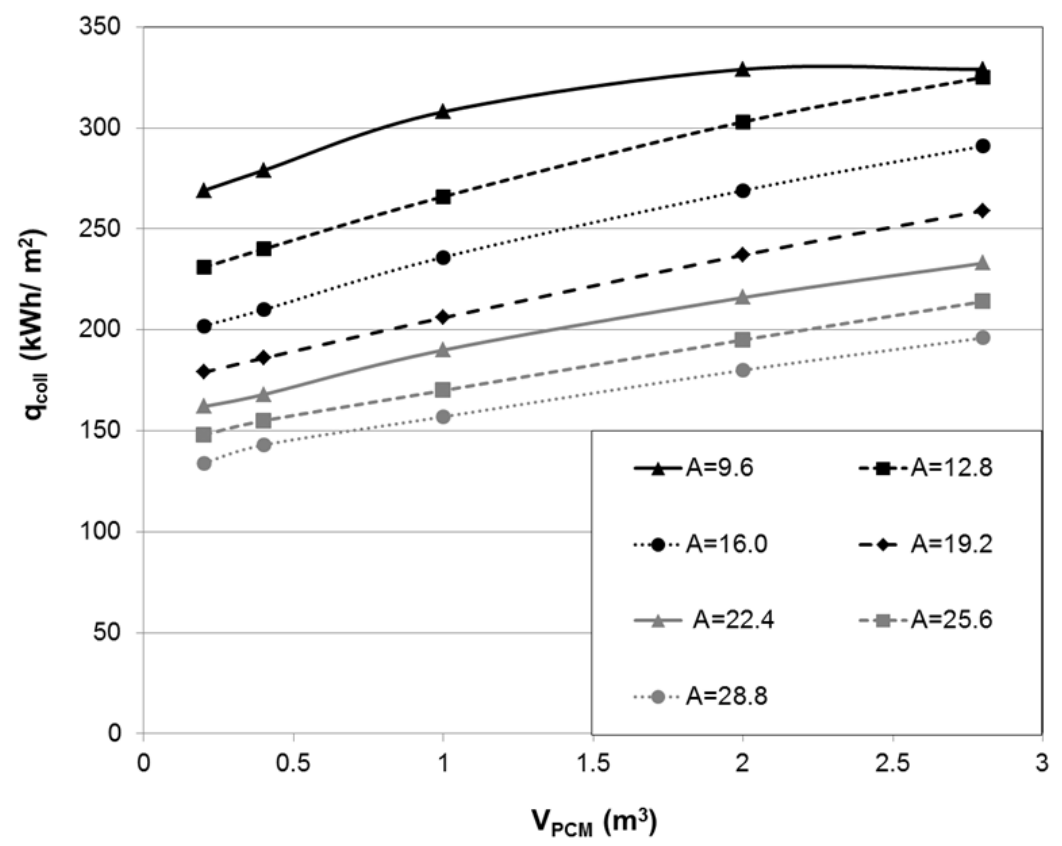

Fig. 8. Solar yield in dependency of collector area and PCM volume $\left(\mathrm{V}_{\text {water }}=0.6 \mathrm{~m}^{3}\right)$.

Fig. 9 presents the number of storage cycles per year $\left(\mathrm{N}_{\mathrm{cycle}}\right)$ in dependency of the collector area. As suggested by Rathgeber et al. [23], $\mathrm{N}_{\text {cycle }}$ should be used as basis for decision on PCM heat storage size. High $\mathrm{N}_{\text {cycle }}$ were calculated for relatively large collector areas and a small number of PCM units. Throughout the year 1-3 PCM units were subject to repeated charge and discharge, while the additional PCM units were utilized seasonally. Larger collector arrays enabled more frequent recharge of a larger PCM volume. Therefore, additional collector panels $\left(A=3.2 \mathrm{~m}^{2}\right)$ increased $\mathrm{N}_{\text {cycle }}$ by about 2 when a single PCM unit was used. This effect was reduced to an increase of 0.35 cycles per year with $\mathrm{V}_{\mathrm{PCM}}=2 \mathrm{~m}^{3}$. 


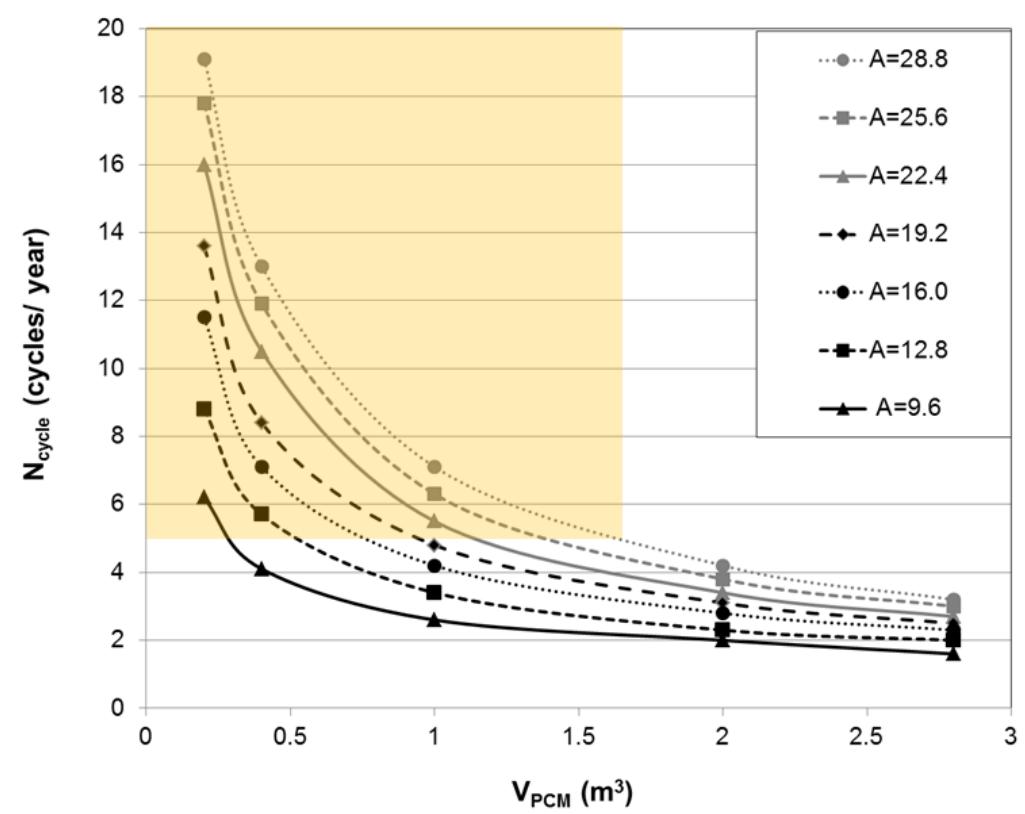

Fig. 9. $\mathrm{N}_{\text {cycle }}$ in dependency of collector area and $\mathrm{PCM}$ volume $\left(\mathrm{V}_{\text {water }}=0.6 \mathrm{~m}^{3}\right.$, initial full-charge of stores).

Since an increase of the collector area results in better utilization of the PCM volume $\left(\mathrm{V}_{\mathrm{PCM}}\right)$ but in lower specific yield, an optimum is warranted. The calculation of attractive system configurations could be based on two assessments:

1. The available roof area of a single-family house is assumed to be $30 \mathrm{~m}^{2}$ enabling the installation of 7 panels $\left(\mathrm{A}=22.4 \mathrm{~m}^{2}\right)$ of the used collector type.

2. Industrial SAT market prices are typically below $0.5 € / \mathrm{kg}$. Considering a PCM unit of $200 \mathrm{~L}(\mathrm{C}=36 \mathrm{kWh})$ could be produced with a cost of $250 €$, specific storage capacity costs of $7 € / \mathrm{kWh}$ could be achieved. This value meets the maximal acceptable storage costs in building application [23] with $\mathrm{N}_{\mathrm{cycle}}=5$. The area of relevant system settings is marked in Fig. 9.

With full storage charge by wind power at the beginning of the year, it was found that attractive combinations would be $\mathrm{V}_{\mathrm{PCM}}=0.4 \mathrm{~m}^{3}$ with $\mathrm{A}=12.8-22.4 \mathrm{~m}^{2}$, resulting in renewable energy fractions from $57 \%$ to $71 \%$. With a PCM volume of 1 $\mathrm{m}^{3}$ a collector area of $22.4 \mathrm{~m}^{2}$ would be attractive, resulting in a REF of $75 \%$.

\subsection{Application potential}

In the solar combi-system, auxiliary heating has to take place when heat is in demand and cannot be covered by stored heat. By simulating full storage charge at the beginning of the year, the heat demand was covered for 2 days with $\mathrm{V}_{\mathrm{PCM}}=0.2 \mathrm{~m}^{3}$ and for 18 days with $\mathrm{V}_{\mathrm{PCM}}=2.8 \mathrm{~m}^{3}$ before auxiliary heating was activated for the first time, where first sensible heat from the water tank and the PCM units and finally latent heat of fusion from the PCM units was utilized for SH and DHW supply. Power-to-heat conversion during these periods could avoid on-demand charging. So, with large PCM heat stores, solar heat and electricity could be utilized with a high degree of flexibility in time. 


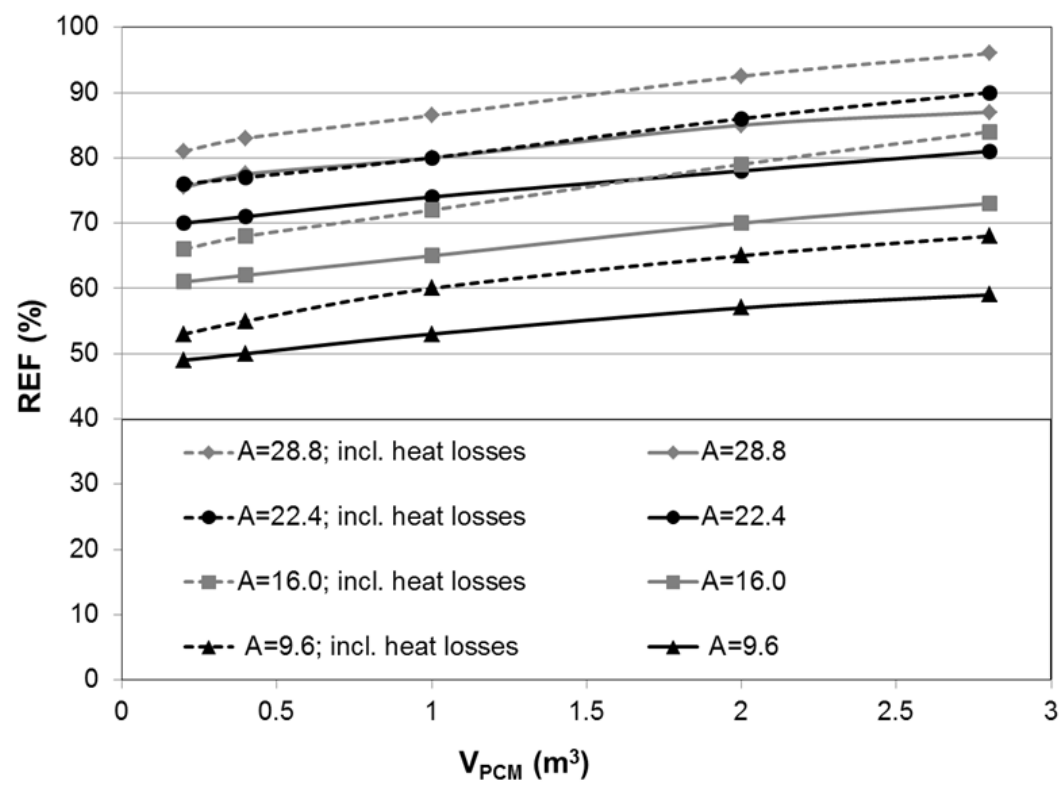

Fig. 10. Renewable energy fractions of the system assuming full storage charge by wind power at the beginning of the year

$$
\left(\mathrm{V}_{\text {water }}=0.6 \mathrm{~m}^{3}\right) \text {. }
$$

Annual renewable energy fractions with full storage charge at the beginning of the year (Fig. 10) would be in between $1 \%\left(\mathrm{~V}_{\mathrm{PCM}}=0.2 \mathrm{~m}^{3}\right)$ and $8 \%\left(\mathrm{~V}_{\mathrm{PCM}}=2.8 \mathrm{~m}^{3}\right)$ higher than calculated solar fractions (Table 6). Placing heat stores in the living area of the house, storage heat losses could be utilized to cover SH demand. Then, REFs could be $6 \%\left(\mathrm{~V}_{\mathrm{PCM}}=0.2 \mathrm{~m}^{3}\right)$ to $18 \%$ $\left(\mathrm{V}_{\mathrm{PCM}}=2.8 \mathrm{~m}^{3}\right)$ higher than calculated SFs. However, this would also require measures to avoid overheating of the building during summer.

In Fig. 11 calculated heat quantities for the potentially attractive system setting with $A=22.4 \mathrm{~m}^{2}, \mathrm{~V}_{\text {water }}=0.6 \mathrm{~m}^{3}$ and $\mathrm{V}_{\mathrm{PCM}}=1 \mathrm{~m}^{3}$ are presented. A SF of $71 \%$ was calculated, which could result in a REF of $80 \%$ by full storage charge at the beginning of the year and by utilizing storage heat losses. System simulation indicated that full heat supply could be achieved by five times of storage re-charge from end-November to the beginning of March. This would potentially enable use of periodically available, cheap electricity from renewable energy sources, such as wind power (section 1.1).

The investigations performed in this paper were based on properties of previous experimental development of prototype stores [40]. These contained SAT composites allowing combined long- and short-term heat storage. Subsequently, functionality tests employing an integrated water tank proved that the storage concept could be applied into a solar combisystem. The presented numerical study of a Danish Passive House employing a solar combi-system with optimized heat storage utilizing on-demand crystallization of SAT showed promising results. It will provide a reference for building heat supply with a solar fraction larger than $70 \%$ using a relatively small storage volume. This system may be applicable for decentralized electrical grid stabilization in regions with a large wind power generation capacity in winter. Further development of heat stores containing SAT composites, emphasizing improved heat transfer, low manufacturing costs and cyclic stability is therefore desirable. 


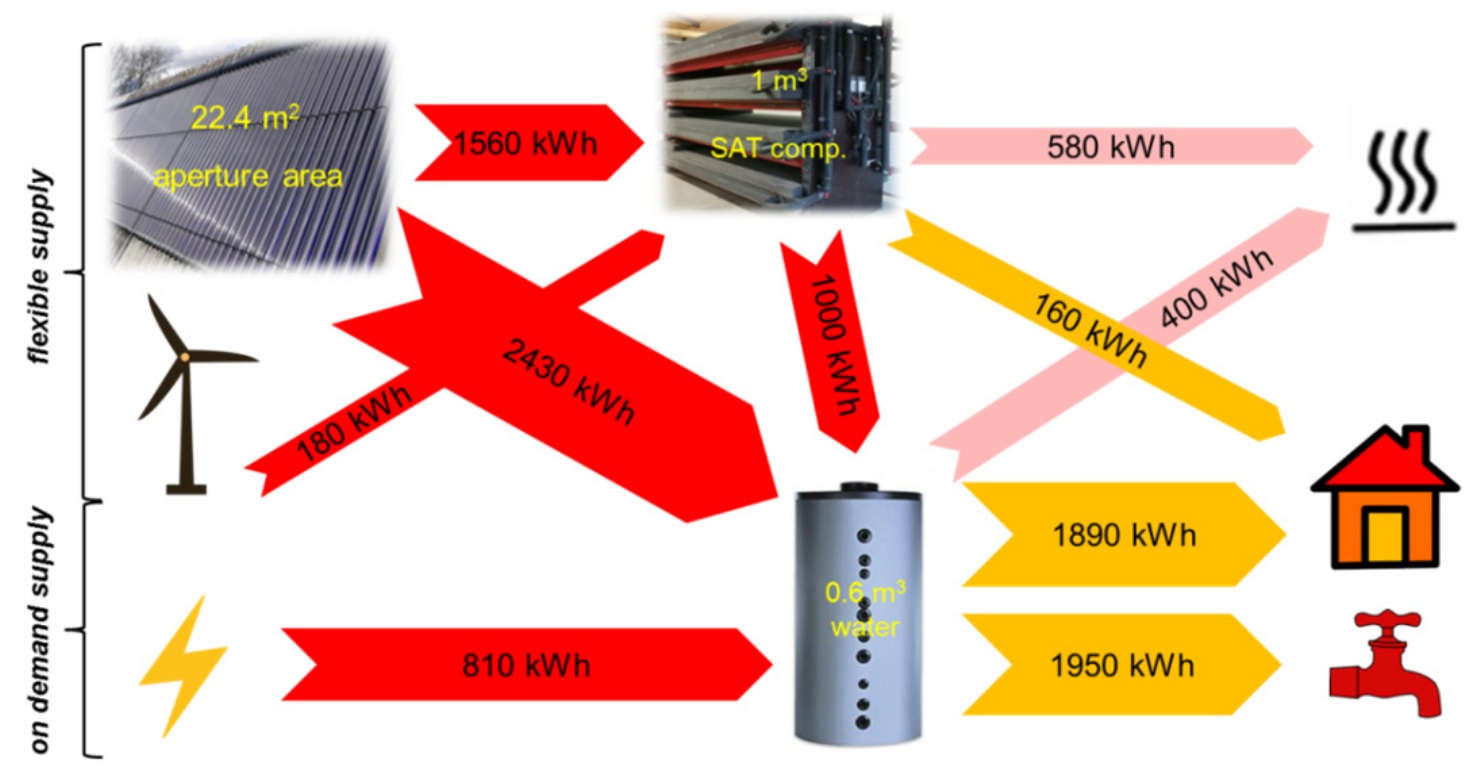

Fig. 11. Annual heat flux (supply in red, demand in orange, heat loss in pink) in a system scenario with a REF of $80 \%$. 


\section{Conclusions}

For the first time, the performance of a solar combi-system with evacuated tubular collectors, water tank and PCM units utilizing stable supercooling of sodium acetate trihydrate was investigated. The validation results of the component models revealed a high degree of similarity with measured data from previous system demonstration. The control strategy included on-demand utilization of heat of fusion of sodium acetate trihydrate composites. Annual simulations showed high potential of the system in a Danish Passive House scenario:

- In spring and autumn, when simulating space heating and domestic hot water patterns, up to three PCM units were subject to repeated charge and discharge, while additional PCM units were utilized as seasonal storage from summer to winter. In this way, combined short and long-term heat storage led to high solar fractions of heat supply.

- With prototype component specification, an annual solar fraction of 56\% was calculated for a yearly, total heat demand of $3723 \mathrm{kWh}$. A scenario with optimized component specifications and a 15\% higher hot water demand (3977 kWh of total heat demand) resulted in a solar fraction of $69 \%$.

- Sensitivity analysis showed an optimal collector array inclination of $70^{\circ}$ with PCM units of $200 \mathrm{~L}$ and a $0.6 \mathrm{~m}^{3}$ water tank. The system was found to perform best with collector aperture areas in between 12.8 and $22.4 \mathrm{~m}^{2}$, with PCM volumes below $1 \mathrm{~m}^{3}$ and when additional storage charge at the beginning of the year was assumed. With $22.4 \mathrm{~m}^{2}$ (aperture) tubular collectors, approximately $1000 \mathrm{kWh}$ heat demand would be covered by $1 \mathrm{~m}^{3}$ sodium acetate trihydrate composite and its heat storage capacity would be utilized 5.5 times per year, those of the water tank 116 times per year respectively.

- Full-charge of a single $200 \mathrm{~L}$ PCM unit and a $0.6 \mathrm{~m}^{3}$ water tank enabled heat supply of 2 days in January, which increased to 18 days when $2.8 \mathrm{~m}^{3}$ of sodium acetate trihydrate composite was charged.

- The heat storage of the system could be charged several times during winter in periods with surplus of wind energy and in summer, spring and autumn by solar collectors. Thus, the system could reveal a renewable energy fraction close to $100 \%$ and would only require a relatively small storage volume.

Application of PCM units with a high number of annual storage cycles is needed due to economic reasons. In contrast, reduction of necessary collector area lowers system costs. Further studies elucidating optimal application of heat stores employing stable supercooling of SAT are warranted. For instance, investigations could be done for different climates, different collector types and cylindrical heat storage units with improved heat transfer properties, etc..

\section{Acknowledgements}

This research was funded by the PhD program of the Sino Danish Center for Education and Research (SDC). The work was also supported by the European Commission (Grant Agreement N_295568) as part of the Seventh Framework Programme of the European Community for Research, Technological Development and Demonstration Activities under the "Collaborative Project" funding scheme of through the COMTES consortium. 


\section{References}

[1] European Parliament, Directive 2012/27/EU of the European Parliament and of the Council of 25 October 2012 on energy efficiency, amending Directives 2009/125/EC and 2010/30/EU and repealing Directives 2004/8/EC and 2006/32/EC. Official Journal of the European Union, 315, pp. 1-56, 2012.

[2] European Parliament, Directive 2010/31/EU of the European Parliament and of the Council of 19 May 2010 on the energy performance of buildings. Official Journal of the European Union, 153, pp. 13-35, 2010.

[3] Weiss W. (Ed.), Solar Heating Systems for Houses, a Design Handbook for Solar Combisystems. James \& James Ltd., UK, 2003.

[4] A. Thür, “Compact solar Combisystem - High Efficiency by Minimizing Temperatures,” PhD thesis, Technical University of Denmark, Department of Civil Engineering report no. R-160, 2007.

[5] S. Colclough and T. McGrath, "Net energy analysis of a solar combi system with Seasonal Thermal Energy Store," Appl. Energy, vol. 147, pp. 611-616, 2015.

[6] DS 439, "Norm for vandinstallationer - Code of Practice for domestic water supply," Danish Standards, 75 pp., 2009.

[7] W. Streicher, R. Heimrath, and C. Bales, "Analysis of System Reports of Task 26 for Sensitivity of Parameters," December 2003 (revised February 2007).

[8] W. Kramer, A. Oliva, G. Stryi-Hipp, S. Kobelt, D. Bestenlehner, H. Drück, J. Bühl, and G. Dasch, "Solar-activehouses - Analysis of the building concept based on detailed measurements," Energy Procedia, vol. 48, pp. 895-903, 2014.

[9] B. Mette, H. Kerskes, H. Drück, and H. Müller-Steinhagen, "New highly efficient regeneration process for thermochemical energy storage,” Appl. Energy, vol. 109, pp. 352-359, 2013.

[10] T. Nonnen, S. Beckert, K. Gleichmann, A. Brandt, B. Unger, H. Kerskes, B. Mette, S. Bonk, T. Badenhop, F. Salg, and R. Gläser, “A Thermochemical Long-Term Heat Storage System Based on a Salt/Zeolite Composite,” Chem. Eng. Technol., vol. 39, no. 12, pp. 2427-2434, 2016.

[11] B. Zettl and H. Kirchsteiger, "An open sorption heat storage application," in Proceedings of the International Sustainable Energy Conference (ISEC) 2018, pp. 605-611, 2018.

[12] B. Zettl, G. Englmair, and G. Steinmaurer, "Development of a revolving drum reactor for open-sorption heat storage processes,” Appl. Therm. Eng., vol. 70, no. 1, pp. 42-49, 2014.

[13] R. Köll, W. van Helden, G. Engel, W. Wagner, B. Dang, J. Jänchen, H. Kerskes, T. Badenhop, and T. Herzog, “An experimental investigation of a realistic-scale seasonal solar adsorption storage system for buildings," Sol. Energy, vol. 155, pp. 388-397, 2017.

[14] R. Weber and V. Dorer, "Long-term heat storage with NaOH," Vacuum, vol. 82, no. 7, pp. 708-716, 2008

[15] B. Fumey, R. Weber, and L. Baldini, "Liquid sorption heat storage - A proof of concept based on lab measurements with a novel spiral fined heat and mass exchanger design,” Appl. Energy, vol. 200, pp. 215-225, 2017.

[16] J. Pereira da Cunha and P. Eames, "Thermal energy storage for low and medium temperature applications using phase change materials - A review,” Appl. Energy, vol. 177, pp. 227-238, 2016.

[17] D. Zhou, C. Y. Zhao, and Y. Tian, "Review on thermal energy storage with phase change materials (PCMs) in building applications," Appl. Energy, vol. 92, pp. 593-605, 2012.

[18] M. Saffari, A. de Gracia, C. Fernández, and L. F. Cabeza, "Simulation-based optimization of PCM melting temperature to improve the energy performance in buildings," Appl. Energy, vol. 202, pp. 420-434, 2017.

[19] A. Kazemian, A. Salari, A. Hakkaki-Fard, and T. Ma, "Numerical investigation and parametric analysis of a 
photovoltaic thermal system integrated with phase change material,” Appl. Energy, vol. 238, pp. 734-746, 2019.

[20] W. Yuan, J. Ji, M. Modjinou, F. Zhou, Z. Li, Z. Song, S. Huang, and X. Zhao, "Numerical simulation and experimental validation of the solar photovoltaic/thermal system with phase change material," Appl. Energy, vol. 232, pp. 715-727, 2018.

[21] N. Araki, M. Futamura, A. Makino, and H. Shibata, "Measurements of Thermophysical Properties of Sodium Acetate Hydrate,” International J. Thermophys., vol. 16, no. 6, pp. 1455-1466, 1995.

[22] M.A. Rogerson and S.S.S. Cardoso, “Solidification in heat packs: I. Nucleation rate,” AIChE J., vol. 49, no. 2, pp. 505-515, 2003.

[23] C. Rathgeber, E. Lävemann, and A. Hauer, "Economic top-down evaluation of the costs of energy storages-A simple economic truth in two equations,” J. Energy Storage, vol. 2, pp. 43-46, 2015.

[24] A. Arteconi, N.J. Hewitt, and F. Polonara, "State of the art of thermal storage for demand-side management," Appl. Energy, vol. 93, pp. 371-389, 2012.

[25] D. Heide, L. von Bremen, M. Greiner, C. Hoffmann, M. Speckmann, and S. Bofinger, "Seasonal optimal mix of wind and solar power in a future, highly renewable Europe,” Renew. Energy, vol. 35, no. 11, pp. 2483-2489, 2010.

[26] F. Hvelplund, P. A. Østergaard, and N. I. Meyer, "Incentives and barriers for wind power expansion and system integration in Denmark,” Energy Policy, vol. 107, pp. 573-584, 2017.

[27] B. Zalba, J.M. Marín, L.F. Cabeza, and H. Mehling, "Review on thermal energy storage with phase change: materials, heat transfer analysis and applications," Appl. Therm. Eng., vol. 23, no. 3, pp. 251-283, 2003.

[28] S. Furbo and S. Svendsen, "Report on heat storage in a solar heating system using salt hydrates," Technical University of Denmark, Thermal Insulation Laboratory, report no. 70, 1977.

[29] W. Kong, M. Dannemand, J.B. Berg, J. Fan, G. Englmair, J. Dragsted and S. Furbo, "Experimental investigations on phase separation for different heights of sodium acetate water mixtures under different conditions," Appl. Therm. Eng., vol. 148, pp. 796-805, 2019.

[30] M. Dannemand, J.B. Johansen, and S. Furbo, "Solidification behavior and thermal conductivity of bulk sodium acetate trihydrate composites with thickening agents and graphite," Sol. Energy Mater. Sol. Cells, vol. 145, Part 3, pp. 287-295, 2016.

[31] M. Dannemand, M. Delgado, A. Lazaro, C. Penalosa, C. Gundlach, C. Trinderup, J.B. Johansen, C. Moser, H. Schranzhofer, and S. Furbo, "Porosity and density measurements of sodium acetate trihydrate for thermal energy storage,” Appl. Therm. Eng., vol. 131, pp. 707-714, 2018.

[32] W. Kong, M. Dannemand, J.B. Johansen, J. Fan, J. Dragsted, G. Englmair, and S. Furbo, "Experimental investigations on heat content of supercooled sodium acetate trihydrate by a simple heat loss method," Sol. Energy, vol. 139, pp. 249-257, 2016.

[33] P.L. Dietz, J.S. Brukner, and C.A. Hollingsworth, "Linear Crystallization Velocities of Sodium Acetate in Supersaturated Solutions,” J. Phys. Chem., vol. 61, no. 7, pp. 944-948, 1957.

[34] G. Englmair, Y. Jiang, M. Dannemand, C. Moser, H. Schranzhofer, S. Furbo, and J. Fan, "Crystallization by local cooling of supercooled sodium acetate trihydrate composites for long-term heat storage," Energy Build., vol. 180, pp. 159-171, 2018.

[35] M. Medrano, M. O. Yilmaz, M. Nogués, I. Martorell, J. Roca, and L. F. Cabeza, "Experimental evaluation of commercial heat exchangers for use as PCM thermal storage systems,” Appl. Energy, vol. 86, no. 10, pp. 20472055, 2009.

[36] A. López-navarro, J. Biosca-Taronger, J.M. Corberán, C. Peñalosa, A. Lázaro, P. Dolado, and J. Payá, "Performance characterization of a PCM storage tank," Appl. Energy, vol. 119, pp. 151-162, 2014. 
[37] A. Frazzica, M. Manzan, A. Sapienza, A. Freni, G. Toniato, and G. Restuccia, "Experimental testing of a hybrid sensible-latent heat storage system for domestic hot water applications," Appl. Energy, vol. 183, pp. 1157-1167, 2016.

[38] C. Zauner, F. Hengstberger, B. Mörzinger, R. Hofmann, and H. Walter, "Experimental characterization and simulation of a hybrid sensible-latent heat storage,” Appl. Energy, vol. 189, pp. 506-519, 2017.

[39] G. Zhou and Y. Xiang, "Experimental investigations on stable supercooling performance of sodium acetate trihydrate PCM for thermal storage,” Sol. Energy, vol. 155, pp. 1261-1272, 2017.

[40] M. Dannemand, J. Dragsted, J. Fan, J.B. Johansen, W. Kong, and S. Furbo, "Experimental investigations on prototype heat storage units utilizing stable supercooling of sodium acetate trihydrate mixtures," Appl. Energy, vol. 169 , pp. 72-80, 2016.

[41] M. Dannemand, J.B. Johansen, W. Kong, and S. Furbo, "Experimental investigations on cylindrical latent heat storage units with sodium acetate trihydrate composites utilizing supercooling,” Appl. Energy, vol. 177, pp. 591601,2016

[42] J. Deng, S. Furbo, W. Kong, and J. Fan, "Thermal performance assessment and improvement of a solar domestic hot water tank with PCM in the mantle," Energy Build., vol. 172, pp. 10-21, 2018.

[43] M. Dannemand, J. M. Schultz, J. B. Johansen, and S. Furbo, "Long term thermal energy storage with stable supercooled sodium acetate trihydrate,” Appl. Therm. Eng., vol. 91, pp. 671-678, 2015.

[44] W. Streicher, J. Bony, S. Citherlet, A. Heinz, P. Pusching, H. Schranzhofer, and J. M. Schultz, "Simulation Models of PCM Storage Units, Report C5, IEA Solar Heating and Cooling programme - Task 32 "Advanced storage concepts for solar and low energy buildings", 2008.

[45] G. Englmair, C. Moser, S. Furbo, M. Dannemand, and J. Fan, "Design and functionality of a segmented heatstorage prototype utilizing stable supercooling of sodium acetate trihydrate in a solar heating system," Appl. Energy, vol. 221, pp. 522-534, 2018.

[46] G. Englmair, S. Furbo, W. Kong, M. Dannemand, J. Fan, and Z. Wang, "Performance Evaluation of a Demonstration System with PCM for Seasonal Heat Storage : Charge with Evacuated Tubular Collectors", Proceedings of the Ises Solar World Congress 2017 - IEA SHC International Conference on Solar Heating and Cooling for Buildings and Industry, 2017.

[47] C. Finck, R. Li, R. Kramer, and W. Zeiler, "Quantifying demand fl exibility of power-to-heat and thermal energy storage in the control of building heating systems," Appl. Energy, vol. 209, pp. 409-425, 2018

[48] TUV Rheinland/DIN CERTCO, "Summary of EN 12975 Test Results, annex to Solar KEYMARK Certificate of Kingspan Thermomax solar collectors," 2011.

[49] Passive House Institute, "Passive House Institute.” [Online]. Available: https://passivehouse.com. [Accessed: 31Oct-2018].

[50] J. B. Johansen, G. Englmair, M. Dannemand, W. Kong, J. Fan, J. Dragsted, B. Perers, and S. Furbo, "Laboratory Testing of Solar Combi System with Compact Long Term PCM Heat Storage," Energy Procedia, vol. 91, pp. 330 $337,2016$.

[51] Department of Civil Engineering, "DTU Climate Station Data, climate data from the Technical University of Denmark." [Online]. Available: http://climatestationdata.byg.dtu.dk/ [Acessed: 30-Sept-2018]. 